\title{
PERBANDINGAN KOMPETENSI GURU PLH DALAM MEMBANGUN MODEL PEMBELAJARAN KREATIF DI SMP NEGERI AKREDITASI A DAN SMP NEGERI AKREDITASI B KOTA PADANG
}

\author{
Zelhendri Zen ${ }^{1}$, Ahmad Johari Bin Sihes ${ }^{2}$ \\ ${ }^{1}$ Postgraduate Student of Ph.D Universiti Teknologi Malaysia \\ ${ }^{2}$ Lecturer of Universiti Teknologi Malaysia
}

\begin{abstract}
The purpose of this study is to analyze the comparison of teachers' competence of Environmental Education Subject at State of SMP in Padang City to build and implement a creative learning model based on school accreditation status. Four indicators of creativity measured in the comparison of teachers' competence to build and apply this creative learning model are 1.) measurement of teacher's competence comparison to build creative learning of fluency thinking element between SMPN with accreditation A and $B$, 2.) Measure teacher's competence to build creative learning of flexible thinking element between SMPN with accreditation $A$ and $B$, 3.) Comparative measurement of teacher's competence to build creative learning of original thinking element between SMPN with accreditation $A$ and $B$, and 4.) complementary measurement of teacher to build creative learning element of elaboration thinking between SMPN with accreditation $A$ and B. Population in this Research are all teacher of Environmental Education Subject as much as 57 in SMPN A- accredited and 57 in SMPN B-accredited with a total of 114 teachers. The research instrument used questionnaires, interviews, observation and documentation. Data analysis was done by using descriptive statistics and inferential statistics consist of validity and reliability, normality, homogeneity and independent ttest. The result of the research shows that there is an increase of competence of environmental education subject teachers between SMPN A-accredited and B-accredited in building creative learning model 1) fluency thinking, 2) flexible thinking, 3) original thinking and 4) elaboration thinking) Teachers of SMPN with A-accredited is better competence to build creative learning model than Teachers of SMPN with B-accredited in Padang city. This is due to the differences in the number of training, the difference in the facilities and learning infrastructure, the difference of the students input when the selection comes in.
\end{abstract}

Keyword: Environmental Education Subject,, Learning, Creative, Acreditation

\section{PENDAHULUAN}

Metode pembelajaran yang diberikan di sekolah untuk setiap mata pelajaran termasuk pembelajaran Muatan Lokal (Mulok) Pendidikan Lingkungan Hidup (PLH), sepatutnya bertujuan untuk mengembangkan pemikiran kreatif siswa. Metode pembelajaran yang diberikan antara lain mencakup kegiatan: mengeksplorasi, menghasilkan, menemukan, menciptakan, membayangkan, mengandai-andai, serta membuat hipotesis (Sternberg, 2003).

Kegiatan tersebut diatas bertujuan agar siswa dapat melatih proses berpikir kreatif yang akan menghasilkan siswa mampu menciptakan dan mengekpresikan ide-ide pemikiran yang baik, baru dan kreatif yang dapat menjadi solusi dalam mengatasi berbagai masalah lingkungan hidup seperti membangun perilaku kreatif memanfaatkan sampah menjadi pupuk, atau memanfaatkan barang bekas menjadi produk kerajinan yang bernilai seperti membuat mainan oleh anak-anak dari barang bekas sebagaimana kereativitas anak tempo dulu yang sanga kreatif membuat mainan mereka sendiri dari barang-barang bekas. Kreativitas ini dikalangan anak-anak dewasa ini terus memudar, selain disebabkan oleh mental pragmatis anak yang hingga saat ini memudar akibat terbiasa membeli maninan secara praktis. Untuk itu pengembangan 
kreativitas perlu dibangun kembali di lingkungan sekolah, terutama membangun kembali kreativitas anak memanfaatkan lingkungan alam mereka sebagai sarana belajar sebagaimana yang menjadi sasaran dalam kurikulum 2013 di Indonesia.

Berdasarkan studi lapangan mengenai kompetensi guru melaksanakan pembelajaran kreatif PLH ditemukan beberapa data empirik yang mengarah pada lemahnya potensi kreativitas nyata peserta didik dalam pembelajaran PLH di beberapa sekolah SMP di Kota Padang, kelemahan tersebut terlihat sebagai berikut:

1. Terdapat beberapa prilaku keseharian siswa yang tidak mengarah pada pengembangan kreativitas, misalnya dalam berpikir lancar sebagai kemampuan berpikir kreatif (aptitude), seperti memberikan banyak cara untuk melakukan berbagai hal, atau mencetuskan banyak ide gagasan, jawaban, penyelesaian masalah lingkungan hidup baik dalam tanya jawab, maupun diskusi di dalam kelas..

2. Ditemukan kekurangmampuan peserta didik dalam mengembangkan keterampilan memperinci (mengelaborasi) sebagai kemampuan berpikir kreatif, seperti kemampuan memperkaya dan mengembangkan suatu gagasan atau produk, atau memperinci detil-detil dari suatu obyek menjadi lebih menarik dan mudah dipahami orang lain, serta tidak terdorong untuk mengembangkan sikap rasa ingin tahu (nonaptitude), misalnya pada bagaimana kemampuan siswa mengelola dan mengurangi limbah.

3. Ditemukan kekurang mampuan peserta didik pada mengembangkan keterampilan berpikir orisinal sekaligus berpikir lancar yang mampu melahirkan kombinasi- kombinasi yang unik, dimana keduanya merupakan ciri berpikir kreatif (aptitude) melalui kreativitas nyata dalam wujud hasil karya kreatif yang dihasilkan..

4. Pendidikan Lingkungan Hidup di sekolah belum memberikan dampak yang positif terhadap perilaku peserta didik dalam mengembangkan berpikir kreatif (aptitude), khususnya pada keterampilan memperinci (mengelaborasi) melalui keinginan memiliki rasa keindahan yang kuat sehingga tidak puas dengan penampilan yang ada, juga pada sikap kreativitas (Non-aptitude), dengan ciri-cirinya antara lain; merasa tertantang, dan bersifat imajinatif untuk memecahkan persoalan- persoalan sehari-hari yang berorientasi kemasa depan.

5. Ditemukan beberapa sikap siswa yang dapat menghambat perkembangan kreativitas, misalnya ketika berdiskusi jarang mencetuskan banyak ide gagasan dengan mengajukan banyak pertanyaan, sikap mereka lebih banyak mengolok-ngolok gagasan teman, dan kurang toleran terhadap gagasan yang berbeda, padahal masalah lingkungan hidup merupakan topik masalah yang kompleks, mulai dari sebab dan akibat baik dalam konteks lokal, nasional, regional, maupun global.

6. Hasil test kompetensi. Dari hasil tes kreativitas di kelas VIII yang diambil dari beberapa SMP di Kota Padang sebagai sampel, diperoleh nilai rata-rata hasil testnya antara $40-44$, artinya hasil tes kreativitas tersebut berada pada interval standar nilai kualifikasi kategori rendah. Sementara dari sisi pencapaian KKM (Kriteria Ketuntasan Minimal), bahwa nilai raport Kelas VIII misalnya dari beberapa kelas pada masing-masing sekolah sebagai sampel yang diambil, umumnya baru mencapai $65 \%$ dari nilai $\mathrm{KKM} 7,5$.

Berdasarkan masalah diatas, maka peneliti tertarik untuk mengkajinya secra mendalam dalam bentuk disertasi dengan mengamati kompetensi guru-guru PLH dalam mengatasi masalah belum terbangunnya kreativitas anak mengikuti pembelajaran PLH di sekolah. Lebih lanjut tujuan penelitian ini adalah untuk menganalisa perbandingan kompetensi guru-guru PLH di SMP Negeri Kota Padang dalam membangun dan melaksanakan model pembelajaran kreatif berdasarkan status akreditasi sekolah dengan topik Perbandingan Kompetensi Guru PLH Membangun Model Pembelajaran Kreatif Berdasarkan akreditasi Sekolah SMP Negeri di Kota Padang.

\section{TINJAUAN LITERATUR}

\section{Kreativitas}

Kreatifitas mempunyai definisi yang beragam tergantung bagaimana penekanannya. Namun pada intinya ada persamaan antara definisidefinisi tersebut yaitu, kreatifitas merupakan kemampuan seseorang untuk melahirkan sesuatu yang baru, baik berupa gagasan maupun karya nyata, yang relatif berbeda dengan apa yang ada sebelumnya (Supriadi, 1994: 7). Di sisi lain Lumsden (Sternberg, 1999: 153) mengemukakan, "creativity is a kind of capacity to think up something new that people find significant". 
Berdasarkan penekanannya, kreatifitas dapat dibedakan ke dalam beberapa aspek diantaranya adalah person, proses, produk, dan press (pendorong) (Supriadi, 2004). Keempat aspek tersebut mempunyai karakteristik yang berbeda, kreatifitas person berkaitan dengan diri seseorang, proses berhubungan dengan kegiatan yang dilakukannya, produk adalah hasil dari suatu aktivitas, dan press merupakan dorongan dari dalam diri seseorang. Pendapat lain menyatakan bahwa untuk mempelajari kreativitas ada empat hal yang sejalan yang harus diperhatikan, yaitu: (1) produk, (2) proses, (3) pengukuran, serta (4) kepribadian. Hal ini dikemukakan oleh Bloomberg sebagai berikut, "How are they studying creativity? Four contemporary emphases are apparent: products, process, measurement, and personality".

\section{Pengembangan Kreatifitas Melalui Proses Belajar}

Dari konsep-konsep proses kreativ berkembang beberapa model pembelajaran kreatif, diantaranya adalah model Renzulli. Model Renzulli yang biasanya disebut model "Enrichment Triad" atau Pengayaan Tiga Tingkat adalah model yang digunakan untuk pengayaan anak-anak berbakat yang menggunakan tiga tingkat kegiatan, yaitu: (1) general exploratory activities; (2) group training activity, dan (3) small group investigations of realworld problems (Munandar, 2002, 2005).

Model Treffinger (1980) merupakan salah satu model pembelajaran yang menangani kreatifitas yang melibatkan aspek kognitif dan afektif. Model ini menyusun setrategi pembelajaran kreatif melalui tiga tingkat aktifitas peserta didik. Ketiga aktifitas ini disusun mulai dari tingkat unsusr-unsur dasar sampai ketingkat berpikir kreatif yang lebih majemuk. Ketiga tingkat aktifitas tersebut adalah: basic tools, practice with process, dan working with real problems

Dari kedua model belajar kreativ di atas secara umum dapat diambil pengertian bahwa proses belajar kreatifitas dilakukan melalui empat tahap aktivitas, yaitu: (1) penjajagan umum; (2) pengembangan ide; (3) seleksi ide; dan (4) realisasi ide.

\section{Indikator Berfikir Kreatif}

Dalam penelitian ini indikator berfikir kreatif yang dikembangkan adalah: 1.) keterampilan berfikir lancar, 2.) keterampilan berfikir fleksibel, 3.) keterampilan berfikir orisinal, 4.) keterampilan memperinc/

Keterampilan berfikir lancar,yaitu mengajukan banyak pertanyaan, menjawab dengan sejumlah jawaban jika ada pertanyaan, mempunyai banyak gagasan mengenai suatu masalah, lancar mengungkapkan gagasannya, bekerja lebih cepat dan melakukan lebih banyak dari pada anak-anak lain, dapat dengan cepat melihat kesalahan.

Keterampilan berfikir fleksibel (luwes), yaitu memberikan macam-macam penafsiran terhadap suatu gambar,cerita atau masalah, menerapkan suatu konsep dengan cara yang berbeda, dalam berdiskusi suatu situasi mempunyai posisi yang berbeda dari mayoritas kelompok, jika diberikan suatu masalah biasanya memikirkan macam-macam cara berbeda untuk menyelesaikannya.

Keterampilan berfikir orisinal, yaitu memikirkan masalah yang tidak pernah terfikirkan oleh orang lain, mempertanyakan cara-cara yang lama dan berusaha memikirkan cara-cara yang baru, setelah membaca atau mendengarkan gagasan bekerja untuk menemukan penyelesaian yang baru.

Keterampilan memperinci (mengelaborasi), yaitu mencari arti yang lebih mendalam terhadap jawaban atas pemecahan masalah dengan melakukan langkah-langkah terperinci, mengembangkan dan memperkaya gagasan orang lain.

\section{METODOLOGI PENELITIAN}

Metode penelitian ini adalah riset dan pengembangan dengan explanatory mixed methods desings. Penggabungan dua pendekatan ini membolehkan peneliti mendapatkan data yang lebih komprehensif bagi membangun desain pembelajaran kreatif yang menjadi tujuan utama kajian ini (Creswell 2007; Wiersma 2000). Penggabungan pendekatan dalam sesebuah penelitian juga dapat memberikan gambaran yang lebih terperinci tentang sesuatu masalah yang diteliti.

Data kuantitatif diperoleh dari angket kreativiitas untuk pemeriksaan pembelajaran kreatif oleh guru pendidikan lingkungan hidup. Dalam bidang sains sosial secara umum, metode gabungan ini telah semakin popular dan boleh dianggap sah, berdiri sendiri sebagai bentuk penelitian. Creswell (2010) gabungan antara metode kualitatif dan kuantitatif dipilih untuk memahami keseluruhan fenomena berbanding dengan hanya menggunakan satu metode saja. Untuk memahami tahap-tahap pengetahuan, perlu mengenal pasti model variabel yang diteliti. Langkah-langkah dan strategi yang diambil dalam membangunkan desain pengajaran pendidikan 
lingkungan hidup mengikuti model fasa pembangunan pembelajaran yang dikembangkan oleh Plom et all (1999) yang telah diperbaiki dengan untuk menggabungkan unsur-unsur model pembelajaran yang dikemukakan oleh Joice, Bruce, Marsha, Weil, \& Baherly, Showers (1996).

Lokasi penelitian ini adalah di Sekolah Mernengah Pertama (SMP) Negeri di Kota Padang. Daerah ini memiliki 19 SMP Negeri akreditasi A dengan 57 guru PLH dan 19 SMP Negeri akreditasi B dengan 57 guru PLH. Total sekolah yang menjadi subjek penelitian adalah 38 sekolah dengan 114 orang guru PLH di Kota Padang. Penelitian ini memakan waktu yang cukup panjang. Lamanya penelitian disebabkan oleh pengamatan, pengawasan dan pelaksanaan pembelajaran di 38 sekolah yang melibatkan 114 orang guru PLH yang mana di masing-masing sekolah menghabiskan setidaknya 15 hari pengamatan sehingga berjumlah 19 bulan. Pengolahan data memakan masa 2 bulan, pengurusan izin penyelidikan 1 bulan, masa pengembangan kerangka pembelajaran kreativiitas 3 bulan, masa oleh data kuantitatif perbandingan 2 bulan sehingga total masa penelitian ini adalah 27 bulan.

Instrumen penelitian sebagai alat pengumpul data dalam penelitian ini menggunakan 1) angket, yang berguna untuk mendaptkan data guru melaksanakan pembelajaran PLH yang berorientasi pada pembangunan berfikir kreatif. Indikator pengukuran kreativitas pelajar dibagi menjadi 4 variabel yaitu 1) berfikir lancar (fluency), berfikir luwes (flexible), berfikir orisinil (original) dan berfikir terinci (elaboration). 2) format wawancara yang berguna untuk mendapatkan respon guru sehubungan dengan pengamalan melaksanakan model pembelajaran kreatif pada pembelajaran PLH di SMP Negeri akreditasi A dan B di Kota Padang.

Analisis data dilakukan menggunakan statistik deskriptif dan statistik infrensial. Sebelum data diproses, terlebih dahulu angket di uji validitas dan reliabilitas. Setelah semua angket valid dan reliable baru data dilakukan uji normalitas dan homogen varians. Ujian normalita bertujuan untuk menentukan sama ada atau tidak taburan data yang diperoleh. Teknik uji normalitas ini menggunakan ujian hipotesis, ujian kehomogenan bertujuan untuk menentukan bahawa kumpulan data sudah homogen dan berasal dari kelompok yang homogen. Setelah data valid, reliable, norma dan homogen, baru data diuji dengan statastik inferensi menggunakan uji independent t-test.

\section{HASIL PENELITIAN DAN PEMBAHASAN}

Hasil analisis data penelitian diperolehi gambaran tentang perbandingan kemampuan aplikasi pembelajaran kreatif pada pendidikan lingkungan hidup antara SMP Negeri akreditasi A dan SMP Negeri akreditasi B di Kota Padang.

\section{Karakteristik Responden}

Sebelum data diolah, maka terlebih dahulu dipaparkan karakteristik responden yang menjadi subjek dalam penelitian ini Untuk lebih jelasnya karakteristik responden berdasarkan umur adalah sebagai berikut:

\section{a. Umur}

Tabel 4.1: Penyebran dan Responden Berdasarkan

\begin{tabular}{|l|c|c|}
\hline \multicolumn{1}{|c|}{ Umur } & $(\mathrm{f})$ & $(\%)$ \\
\hline $21-25$ tahun & 9 & 7.9 \\
\hline 26-30 tahun & 36 & 31.6 \\
\hline $31-35$ tahun & 20 & 17.5 \\
\hline $36-40$ tahun & 22 & 19.3 \\
\hline $41-45$ tahun & 15 & 13.2 \\
\hline 45 tahun ke atas & 12 & 10.5 \\
\hline Jumlah & 114 & 100 \\
\hline
\end{tabular}

Tabel 4.1 menunjukkan frekuensi data dan persentase responden mengikut umur. Berdasarkan tabel di atas hasil kajian menunjukkan sampel yang paling sedikit terlibat dalam kajian ini ialah guru yang berumur antara 21 hingga 25 tahun (7.9\%), diikuti umur 45 tahun ke atas dan 41-45 tahun yang masing-msingnya 15 orang (13.2\%) dan 12 orang $(10.5 \%)$. Kemudian yang agak ramai adalah umur 36 hingga 40 tahun dan 31 hingga 35 tahun yang mempunyai bilangan responden masing-masing 22 $(19.3 \%)$ dan 20 (17.5\%). Sampel yang paling ramai terlibat dalam kajian ini ialah guru yang berumur 31 hingga 35 tahun yang mempunyai jumlah responden iaitu 36 orang $(31.6 \%)$

\section{b. Jenis Kelamin}

Tabel 4.2: Frekuensi data dan Persentase Responden berdasarkan jenis kelamin

\begin{tabular}{|l|c|c|}
\hline Jenis kelamin & (f) & $(\%)$ \\
\hline Lelaki & 29 & 25.4 \\
\hline Perempuan & 85 & 74.6 \\
\hline Jumlah & 114 & 100 \\
\hline
\end{tabular}

Pada tabel 4.2 menunjukkan frekuensi data dan persentase responden mengikut jenis kelamin. Terdapat 29 orang $(25.4 \%)$ sampel guru lelaki dan 
85 orang $(74.6 \%)$ sampel guru perempuan. Sampel dalam kajian ini adalah seramai 114 orang guru.

\section{c. Status Perkawinan}

Tabel 4.3: Frekuensi data dan Persentase Responden Berdasarkan Status Perkawinan

\begin{tabular}{|l|c|c|}
\hline \multicolumn{1}{|c|}{ Jenis kelamin } & (f) & (\%) \\
\hline Belum Menikah & 8 & 7.0 \\
\hline Menikah & 106 & 93.0 \\
\hline Jumlah & 114 & 100 \\
\hline
\end{tabular}

Merujuk tabel 4.3 menunjukkan frekuensi data dan persentase responden mengikut status perkawinan, terdapat 8 orang $(7.0 \%)$ sampel guru belum menikah atau sudah menikah dan 106 orang (93.0\%) sampel guru berkahwin.

\section{d. Berdasarkan Pendidikan}

Tabel 4.4: Frekuensi data dan Persentase

Responden Mengikut Kelayakan Akademik

\begin{tabular}{|l|c|c|}
\hline \multicolumn{1}{|c|}{ Pendidikan } & (f) & (\%) \\
\hline Post Graduate (S2) & 11 & 9.6 \\
\hline Sarjana S1 & 99 & 86.8 \\
\hline Diploma & 4 & 3.5 \\
\hline Jumlah & 114 & 100 \\
\hline
\end{tabular}

Merujuk tabel 4.4 menunjukkan frekuensi data dan persentase responden mengikut kelayakan akademik tertinggi, terdapat 11 orang $(9.6 \%)$ sampel guru master, 99 orang $(86.8 \%)$ guru sarjjana pendidikan S1 4 orang (3.5\%) sampel guru diploma.

\section{Analisis Deskriptif Kompetensi Guru Melaksanakan Elemen-Elemen} Kreativiitas dalam Pembelajaran Pendidikan Lingkungan Hidup

a. Analisis Deskriptif Kompetensi Guru Melaksanakan Elemen-Elemen Kreativiitas dalam Pembelajaran Pendidikan Lingkungan Hidup pada SMP Negeri Akreditasi A di Kota Padang

Penelitian dilaksanakan dengan menyebarkan angket kepada 57 orang responden guru Pendidilan Lingkungan Hidup (PLH) di SMP Negeri Akreditasi A Kota Padang. Angket menggunakan skala likert yang diberikan dengan alternatif jawaban 1) Tidak Pernah, 2) Jarang, 3) Kadang-kdang, 4) Sering dan 5) selalu. Keputusan kompetensi daripada 57 orang guru PLH pada sekolah SMP Negeri Akreditasi A di Kota Padang adalah sebagai berikut:

Gambar 4.1: Elemen Kreativiitas: Satu Kajian di Sekolah Menengah SMP Negeri Daerah Kota Padang akreditasi A

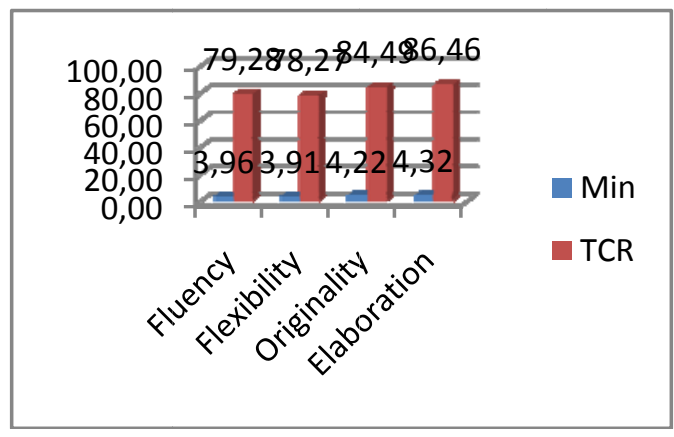

Graf 4.1 menunjukkan tahap kreativiitas satu kajian di Sekolah Menengah SMP Negeri akreditasi A Daerah Kota Padang. Elemen berfikir rinci (elaboration) mempunyai nilai min yang paling tinggi iaitu 3.17 dengan TCR 86.46, diikuti berfikir origisinil (originality) dengan nilai min 4.22 dan TCR 84.49. kemudian elemen berfikir lancar (fluency) dengan nilai min 3.96 dengan TCR 79.28 dan yang paling rendah adalah berfikir luwes (flexibility) dengan nilai min 3.91 dan TCR 78.27. Ini jelas menunjukkan bahawa elemen berfikir terinci adalah aspek kreativiitas yang paling banyak dimiliki oleh guru-guru yang mengajar pendidikan lingkungan hidup di sekolah SMP Negeri Akreditasi A di Kota Padang.

\section{1) Elemen Berfikir Lancar (Fluency) suatu kajian di Sekolah Menengah SMP Negeri Akreditasi A Kota Padang}

Penjelasan elemen-elemen kreativiitas dalam pembelajaran PLH di Sekolah Menengah SMP Negeri Akreditasi A di daerah Kota Padang dapat diuraikan berdasarkan masing-masing elemen-elemen yang diukur yaitu 1) Berfikir Lancar (Fluency), 2) Berfikir Luwes (flexebility), 3) Berfikir orisinil (originality), dan 4) berfikir rinci (elaboration. Untuk lebih jelasnya berikut pengukuran elemen berfikir lancar (fluency). 
Tabel 4.6: Tahapan Kreativiitas Variabel Berfikir Lancar di SMP Negeri akreditasi A Kota Padang

\begin{tabular}{|c|c|c|c|c|c|c|c|c|c|}
\hline $\begin{array}{l}\text { No } \\
\text { soa } \\
\text { lan }\end{array}$ & $\begin{array}{c}\text { Sub Variabel } \\
\text { Elemen Berfikir Lancar } \\
\text { (Fluency) }\end{array}$ & 压 & 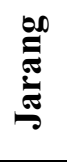 & 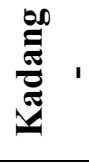 & 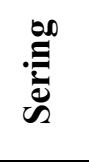 & $\frac{\Xi}{\frac{E}{d}}$ & Min & TCR & Kategori \\
\hline 1 & \multirow{4}{*}{$\begin{array}{l}\text { Mengajukan Banyak } \\
\text { Pertanyaan }\end{array}$} & 0 & 0 & 15 & 22 & 20 & 4.09 & 81.8 & Tinggi \\
\hline 2 & & 0 & 1 & 27 & 20 & 9 & 3.65 & 73.0 & Sedang \\
\hline 3 & & 0 & 1 & 20 & 19 & 17 & 3.91 & 78.2 & Sedang \\
\hline \multirow[t]{2}{*}{4} & & 0 & 2 & 16 & 22 & 18 & 3.98 & 79.6 & Sedang \\
\hline & Jumlah & 0 & 4 & 77 & 83 & 64 & 3.91 & 78.2 & Sedang \\
\hline 5 & \multirow{4}{*}{$\begin{array}{l}\text { Menjawab Pertanyaan saat } \\
\text { ditanya }\end{array}$} & 0 & 0 & 18 & 30 & 9 & 3.84 & 76.8 & Sedang \\
\hline 6 & & 0 & 0 & 17 & 20 & 20 & 4.05 & 81.1 & Sedang \\
\hline 7 & & 0 & 1 & 18 & 22 & 16 & 3.93 & 78.6 & Sedang \\
\hline \multirow[t]{2}{*}{8} & & 0 & 3 & 19 & 20 & 15 & 3.82 & 76.5 & Sedang \\
\hline & Jumlah & 0 & 4 & 72 & 92 & 80 & 3.91 & 78.2 & Sedang \\
\hline 9 & \multirow{6}{*}{ Mempunyai banyak gagasan } & 0 & 3 & 13 & 22 & 19 & 4.00 & 80.0 & Tinggi \\
\hline 10 & & 0 & 5 & 9 & 24 & 19 & 4.00 & 80.0 & Tinggi \\
\hline 11 & & 0 & 3 & 16 & 22 & 16 & 3.89 & 77.9 & Sedang \\
\hline 12 & & 0 & 3 & 17 & 20 & 17 & 3.89 & 77.9 & Sedang \\
\hline 13 & & 0 & 3 & 13 & 24 & 17 & 3.96 & 79.3 & Sedang \\
\hline \multirow[t]{2}{*}{14} & & 0 & 0 & 13 & 27 & 17 & 4.07 & 81.4 & Tinggi \\
\hline & Jumlah & 0 & 17 & 81 & 139 & 105 & 3.97 & 79.4 & Sedang \\
\hline 15 & \multirow{6}{*}{$\begin{array}{l}\text { Lancar mengungkapkan } \\
\text { gagasan }\end{array}$} & 0 & 1 & 18 & 22 & 16 & 3.93 & 78.6 & Sedang \\
\hline 16 & & 0 & 1 & 26 & 14 & 16 & 3.79 & 75.8 & Sedang \\
\hline 17 & & 0 & 3 & 16 & 19 & 19 & 3.95 & 78.9 & Sedang \\
\hline 18 & & 0 & 4 & 11 & 18 & 24 & 4.09 & 81.8 & Tinggi \\
\hline 19 & & 0 & 1 & 19 & 18 & 19 & 3.96 & 79.3 & Sedang \\
\hline \multirow[t]{2}{*}{20} & & 0 & 2 & 18 & 22 & 15 & 3.88 & 77.5 & Sedang \\
\hline & Jumlah & 0 & 12 & 108 & 113 & 109 & 3.93 & 78.7 & Sedang \\
\hline 21 & \multirow{5}{*}{$\begin{array}{l}\text { Berfikir dan bekerja lebih } \\
\text { cepat }\end{array}$} & 0 & 2 & 17 & 16 & 22 & 4.02 & 80.4 & Tinggi \\
\hline 22 & & 0 & 0 & 20 & 25 & 12 & 3.86 & 77.2 & Sedang \\
\hline 23 & & 0 & 2 & 15 & 23 & 17 & 3.96 & 79.3 & Sedang \\
\hline 24 & & 0 & 0 & 13 & 21 & 23 & 4.18 & 85.5 & Tinggi \\
\hline \multirow[t]{2}{*}{25} & & 0 & 2 & 11 & 29 & 15 & 4.00 & 80.0 & Tinggi \\
\hline & Jumlah & 0 & 6 & 76 & 114 & 89 & 4.00 & 80.0 & Tinggi \\
\hline 26 & \multirow{5}{*}{$\begin{array}{l}\text { Dapat melakukan koreksi } \\
\text { dengan cepat }\end{array}$} & 0 & 0 & 20 & 23 & 14 & 3.89 & 77.9 & Sedang \\
\hline 27 & & 0 & 0 & 15 & 18 & 24 & 4.16 & 83.2 & Tinggi \\
\hline 28 & & 0 & 1 & 19 & 18 & 19 & 3.96 & 79.3 & Sedang \\
\hline 29 & & 0 & 0 & 15 & 19 & 23 & 4.14 & 82.8 & Tinggi \\
\hline \multirow[t]{3}{*}{30} & & 0 & 1 & 22 & 17 & 17 & 3.88 & 77.5 & Sedang \\
\hline & Jumlah & 0 & 2 & 91 & 95 & 97 & 4.01 & 80.1 & Tinggi \\
\hline & \multicolumn{6}{|l|}{ Purata } & 3.96 & 79.28 & Sedang \\
\hline
\end{tabular}

Tabel 4.6 menunjukkan analisis deskriptif frekuensi data, persentase, min dan total capaian responden (TCR) mengikut sub variabel elemen berfikir lancar (fluency). Nilai sub variabel "mengajukan banyak pertanyaan" mempunyai nilai min 3.91 dengan TCR adalah $78.2 \%$ yang berada pada tahapan "sedang". Sementara itu nilai sub variabel "menjawab pertanyaan saat ditanya" mempunyai nilai min 3.91 dengan TCR adalah 78.2 \% yang juga berada pada tahapan "sedang". Selanjutnya nilai sub variabel "mempunyai banyak gagasan" mempunyai nilai min 3.97 dengan TCR adalah $79.4 \%$ yang juga berada pada tahapan "sedang". Begitu juga dengan nilai sub variabel "lancar mengungkapkan gagasan" mempunyai nilai min 3.93 dengan TCR adalah $78.7 \%$ yang juga 
berada pada tahapan "sedang". Nilai sub variabel "berfikir dan bekerja lebih cepat didapatakan nilai min 4.00 dengan TCR 80.0 berada pada tahapan tinggi. Terakhir nilai sub variabel dapat melakukan koreksi dengan cepat diperolehi nilai Min 4.01 dengan TCR 80.1 beradap pada tahapan tinggi. Secara keseluruhan diperoleh purata kemampuan guru dalam membangun pembela-jaran yang boleh menstimulasi elemen berfikir lancar adalah 3.96 dengan TCR sebesar $79.28 \%$, berada pada tahapan sedang.

\section{2) Berfikir Luwes (Flexibility) suatu kajian di Sekolah Menengah SMP Negeri Akreditasi A Kota Padang}

Penjelasan elemen-elemen kreativiitas dalam pembelajaran PLH di Sekolah Menengah SMP Negeri Akreditasi A di daerah Kota Padang untuk pengukuran elemen berfikir luwes dapat dilihat pada tabel berikut ini:

Tabel 4.7: Tahapan Kreativiitas Variabel Berfikir Luwes di SMP Negeri Akreditasi A Kota Padang

\begin{tabular}{|c|c|c|c|c|c|c|c|c|c|}
\hline $\begin{array}{l}\text { No } \\
\text { soa } \\
\text { lan }\end{array}$ & $\begin{array}{c}\text { Sub Variabel } \\
\text { Elemen Berfikir Luwes } \\
\text { (Flexibility) }\end{array}$ & 紊 & 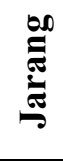 & 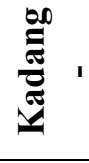 & $\stackrel{\infty}{:}$ & $\frac{\Xi}{\frac{E}{\varpi}}$ & Min & TCR & Ket \\
\hline 1 & \multirow{4}{*}{$\begin{array}{l}\text { Kemahiran menggunakan } \\
\text { berbagai objek dalam } \\
\text { pembelajaran }\end{array}$} & 0 & 0 & 22 & 19 & 16 & 3.89 & 77.9 & Sedang \\
\hline 2 & & 0 & 0 & 22 & 20 & 15 & 3.88 & 77.5 & Sedang \\
\hline 3 & & 0 & 0 & 17 & 23 & 17 & 4.00 & 80.0 & Tinggi \\
\hline \multirow[t]{2}{*}{4} & & 0 & 0 & 18 & 24 & 15 & 3.95 & 78.9 & Sedang \\
\hline & Jumlah & 0 & 0 & 79 & 86 & 63 & 3.93 & 78.6 & Sedang \\
\hline 5 & \multirow{4}{*}{$\begin{array}{l}\text { Kemahiran menafsirkan } \\
\text { berbagai gambar, cerita } \\
\text { dan masalah }\end{array}$} & 0 & 0 & 21 & 21 & 15 & 3.89 & 77.9 & Sedang \\
\hline 6 & & 0 & 1 & 19 & 21 & 16 & 3.91 & 78.2 & Sedang \\
\hline 7 & & 0 & 0 & 16 & 26 & 15 & 3.98 & 79.6 & Sedang \\
\hline \multirow[t]{2}{*}{8} & & 0 & 0 & 25 & 21 & 11 & 3.78 & 75.1 & Sedang \\
\hline & Jumlah & 0 & 1 & 81 & 89 & 57 & 3.89 & 77.7 & Sedang \\
\hline 9 & \multirow{6}{*}{$\begin{array}{l}\text { Kemahrian menerapkan } \\
\text { konsep dengan berbagai } \\
\text { cara }\end{array}$} & 0 & 0 & 14 & 24 & 19 & 4.09 & 81.8 & Tinggi \\
\hline 10 & & 0 & 1 & 19 & 24 & 13 & 3.86 & 77.2 & Sedang \\
\hline 11 & & 0 & 1 & 12 & 18 & 26 & 4.21 & 84.2 & Tinggi \\
\hline 12 & & 0 & 0 & 23 & 24 & 10 & 3.77 & 75.4 & Sedang \\
\hline 13 & & 0 & 1 & 22 & 13 & 21 & 3.95 & 78.9 & Sedang \\
\hline \multirow[t]{2}{*}{14} & & 0 & 1 & 23 & 24 & 9 & 3.72 & 74.4 & Sedang \\
\hline & Jumlah & 0 & 4 & 113 & 127 & 98 & 3.93 & 78.7 & Sedang \\
\hline 15 & \multirow{6}{*}{$\begin{array}{l}\text { Kemahiran mengatasi } \\
\text { berbagai situasi }\end{array}$} & 0 & 1 & 28 & 19 & 9 & 3.63 & 72.6 & Sedang \\
\hline 16 & & 0 & 0 & 28 & 8 & 21 & 3.88 & 77.5 & Sedang \\
\hline 17 & & 0 & 1 & 32 & 4 & 20 & 3.75 & 75.1 & Sedang \\
\hline 18 & & 0 & 0 & 29 & 7 & 21 & 3.86 & 77.2 & Sedang \\
\hline 19 & & 0 & 1 & 22 & 13 & 21 & 3.95 & 78.9 & Sedang \\
\hline \multirow[t]{2}{*}{20} & & 0 & 0 & 28 & 11 & 18 & 3.82 & 76.5 & Sedang \\
\hline & Jumlah & 0 & 3 & 167 & 62 & 110 & 3.82 & 76.3 & Sedang \\
\hline 21 & \multirow{7}{*}{$\begin{array}{l}\text { Kemahiran melahirkan } \\
\text { ide-ide baru }\end{array}$} & 0 & 1 & 13 & 22 & 21 & 4.11 & 82.1 & Tinggi \\
\hline 22 & & 0 & 2 & 12 & 23 & 20 & 4.07 & 81.4 & Tinggi \\
\hline 23 & & 0 & 2 & 21 & 17 & 17 & 3.86 & 77.2 & Sedang \\
\hline 24 & & 0 & 0 & 22 & 15 & 20 & 3.96 & 79.3 & Sedang \\
\hline 25 & & 0 & 0 & 24 & 23 & 10 & 3.75 & 75.1 & Sedang \\
\hline 26 & & 0 & 0 & 23 & 18 & 16 & 3.88 & 77.5 & Sedang \\
\hline \multirow[t]{2}{*}{27} & & 0 & 0 & 26 & 15 & 16 & 3.82 & 76.5 & Sedang \\
\hline & Jumlah & 0 & 5 & 141 & 133 & 120 & 3.92 & 78.4 & Sedang \\
\hline 28 & \multirow{2}{*}{$\begin{array}{l}\text { Mampu menyelesaikan } \\
\text { permasalahan dengan cara }\end{array}$} & 0 & 1 & 25 & 10 & 21 & 3.89 & 77.9 & Sedang \\
\hline 29 & & 0 & 2 & 18 & 23 & 14 & 3.86 & 77.2 & Sedang \\
\hline
\end{tabular}




\begin{tabular}{|c|c|c|c|c|c|c|c|c|c|}
\hline 30 & \multirow{3}{*}{ yang berbeda } & 0 & 1 & 19 & 18 & 19 & 3.96 & 79.3 & Sedang \\
\hline \multirow{3}{*}{32} & & 0 & 0 & 24 & 14 & 19 & 3.91 & 78.2 & Sedang \\
\hline & & 0 & 0 & 18 & 24 & 15 & 3.95 & 78.9 & Sedang \\
\hline & Jumlah & 0 & 4 & 104 & 89 & 88 & 3.92 & $\begin{array}{l}78.3 \\
\end{array}$ & Sedang \\
\hline 33 & \multirow{5}{*}{$\begin{array}{l}\text { Mahir mengklasifikaskan } \\
\text { permasalahan dengan baik }\end{array}$} & 0 & 1 & 18 & 17 & 21 & 4.02 & 80.4 & Tinggi \\
\hline 34 & & 0 & 2 & 22 & 16 & 17 & 3.84 & 76.8 & Sedang \\
\hline 35 & & 0 & 2 & 19 & 10 & 26 & 4.05 & 81.1 & Tinggi \\
\hline 36 & & 0 & 2 & 20 & 14 & 21 & 3.95 & 78.9 & Sedang \\
\hline \multirow[t]{2}{*}{37} & & 0 & 1 & 20 & 11 & 25 & 4.05 & 81.1 & Tinggi \\
\hline & Jumlah & 0 & 8 & 99 & 68 & 110 & 3.98 & 79.6 & Sedang \\
\hline 38 & \multirow{5}{*}{$\begin{array}{l}\text { Mampu mengubah arah } \\
\text { berfikir secara spontan }\end{array}$} & 0 & 2 & 19 & 19 & 17 & 3.89 & 77.9 & Sedang \\
\hline 39 & & 0 & 0 & 18 & 20 & 19 & 4.02 & 80.4 & Tinggi \\
\hline 40 & & 0 & 1 & 17 & 12 & 27 & 4.14 & 82.8 & Tinggi \\
\hline 41 & & 0 & 2 & 19 & 18 & 18 & 3.91 & 78.2 & Sedang \\
\hline \multirow[t]{3}{*}{42} & & 0 & 8 & 17 & 19 & 13 & 3.65 & 73.0 & Sedang \\
\hline & Jumlah & 0 & 13 & 90 & 88 & 94 & 3.92 & 78.5 & Sedang \\
\hline & \multicolumn{6}{|l|}{ Purata } & 3.91 & 78.27 & Sedang \\
\hline
\end{tabular}

Tabel 4.7 menunjukkan analisis deskriptif frekuensi data, persentase, min dan total capaian responden (TCR) mengikut sub variabel elemen berfikir luwes (flexibility). Nilai sub variabel "kemahiran $\mathrm{m}$ enggunakan berbagai obek dalam pembelajaran" mempunyai nilai min 3.93 dengan TCR adalah $78.6 \%$ yang berada pada tahapan "sedang". Sementara itu nilai sub variabel "kemahiran menafsirkan berbagai gambar, cerita dan masalah" mempunyai nilai min 3.89 dengan TCR adalah $77.7 \%$ yang juga berada pada tahapan "sedang". Selanjutnya nilai sub variabel "kemahiran mengatasi berbagai situasi" mempunyai nilai min 3.82 dengan TCR adalah 76.3 \% yang juga berada pada tahapan "sedang". Begitu juga dengan nilai sub variabel "kemahiran melahirkan ide-ide baru" mempunyai nilai min 3.92 dengan TCR adalah $78.4 \%$ yang juga berada pada tahapan "sedang". Nilai sub variabel "mahir menyelesaikan masalah dengan cara yang berbeda" didapatakan nilai min 3.92 dengan TCR 78.3 berada pada tahapan sedang. Untuk sub variabel "mahir mengklasifikasikan permasalahan dengan baik" didapatakan nilai min 3.98 dengan TCR 79.6 berada pada tahapan sedang. Terakhir nilai sub variabel "mampu mengubah arah berfikir secra spontan" diperolehi nilai Min 3.92 dengan TCR 78.5 beradap pada tahapan sedang. Secara keseluruhan diperoleh purata kemampuan guru dalam membangun pembelajaran yang boleh menstimulasi elemen berfikir luwes adalah 3.91 dengan TCR sebesar $78.27 \%$, berada pada tahapan sedang.

\section{3) Berfikir Orisinil (originality) suatu kajian di Sekolah Menengah SMP Negeri Akreditasi A Kota Padang}

Penjelasan elemen-elemen kreativiitas dalam pembelajaran PLH di Sekolah Menengah SMP Negeri Akreditasi A di daerah Kota Padang untuk pengukuran elemen berfikir orisinil dapat dilihat pada tabel berikut ini:

Tabel 4.8: Tahapan Kreativiitas Variabel Berfikir Orisinil di SMP Negeri Akreditasi A Kota Padang

\begin{tabular}{|c|c|c|c|c|c|c|c|c|c|}
\hline $\begin{array}{l}\text { No } \\
\text { soa } \\
\text { lan }\end{array}$ & $\begin{array}{c}\text { Sub Variabel } \\
\text { Elemen Berfikir Orisinil } \\
\text { (Originality) }\end{array}$ & 关 & 羿 & 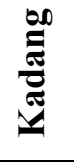 & 易 & $\frac{\Xi}{\frac{\pi}{0}}$ & Min & TCR & Kategori \\
\hline 1 & \multirow{4}{*}{$\begin{array}{l}\text { Mampu melahirkan ide baru } \\
\text { yang tidak pernah } \\
\text { terfikirkan orang lain }\end{array}$} & 0 & 0 & 17 & 18 & 22 & 4.09 & 81.8 & Tinggi \\
\hline 2 & & 0 & 0 & 15 & 22 & 20 & 4.09 & 81.8 & Tinggi \\
\hline 3 & & 0 & 0 & 6 & 17 & 34 & 4.49 & 89.8 & Tinggi \\
\hline 4 & & 0 & 0 & 13 & 22 & 22 & 4.16 & 83.2 & Tinggi \\
\hline & Jumlah & 0 & 0 & 51 & 79 & 98 & 4.21 & 84.1 & Tinggi \\
\hline 5 & Mampu berfikir kritis dalam & 0 & 0 & 15 & 20 & 22 & 4.12 & 82.5 & Tinggi \\
\hline
\end{tabular}




\begin{tabular}{|c|c|c|c|c|c|c|c|c|c|}
\hline 6 & \multirow{3}{*}{$\begin{array}{l}\text { mencari cara-cara baru } \\
\text { untuk menyelesaikan } \\
\text { masalah }\end{array}$} & 0 & 0 & 1 & 31 & 25 & 7.42 & 88.4 & Tinggi \\
\hline 7 & & 0 & 0 & 9 & 23 & 25 & 4.28 & 85.6 & Tinggi \\
\hline 8 & & 0 & 0 & 11 & 15 & 31 & 4.35 & 87.0 & Tinggi \\
\hline & Jumlah & 0 & 0 & 43 & 87 & 98 & 4.24 & 84.8 & Tinggi \\
\hline 9 & \multirow[t]{6}{*}{ Mahir berfikir asimetris } & 0 & 0 & 10 & 22 & 25 & 4.26 & 85.3 & Tinggi \\
\hline 10 & & 0 & 0 & 1 & 31 & 25 & 4.42 & 88.4 & Tinggi \\
\hline 11 & & 0 & 0 & 15 & 21 & 21 & 4.11 & 82.1 & Tinggi \\
\hline 12 & & 0 & 0 & 8 & 23 & 26 & 4.32 & 86.3 & Tinggi \\
\hline 13 & & 0 & 0 & 16 & 22 & 19 & 4.05 & 81.1 & Tinggi \\
\hline \multirow[t]{2}{*}{14} & & 0 & 0 & 13 & 26 & 19 & 4.11 & 82.1 & Tinggi \\
\hline & Jumlah & 0 & 0 & 57 & 146 & 139 & 4.24 & 84.4 & Tinggi \\
\hline 15 & \multirow{6}{*}{$\begin{array}{l}\text { Mampu memikirkan hal-hal } \\
\text { yang berbeda (sesuatu yang } \\
\text { baru) }\end{array}$} & 0 & 0 & 17 & 16 & 24 & 4.12 & 82.5 & Tinggi \\
\hline 16 & & 0 & 0 & 16 & 10 & 31 & 4.26 & 85.3 & Tinggi \\
\hline 17 & & 0 & 0 & 15 & 21 & 21 & 4.11 & 82.1 & Tinggi \\
\hline 18 & & 0 & 0 & 10 & 19 & 28 & 4.32 & 86.3 & Tinggi \\
\hline 19 & & 0 & 0 & 12 & 20 & 25 & 4.23 & 84.6 & Tinggi \\
\hline \multirow[t]{2}{*}{20} & & 0 & 0 & 9 & 22 & 26 & 4.30 & 86.0 & Tinggi \\
\hline & Jumlah & 0 & 0 & 79 & 108 & 155 & 4.22 & 84.4 & Tinggi \\
\hline 21 & \multirow{7}{*}{$\begin{array}{l}\text { Mahir mencari pendekatan } \\
\text { dalam menyelesaikan } \\
\text { berbagai model } \\
\text { permasalahan }\end{array}$} & 0 & 0 & 15 & 23 & 19 & 4.07 & 81.4 & Tinggi \\
\hline 22 & & 0 & 1 & 12 & 15 & 25 & 4.26 & 85.3 & Tinggi \\
\hline 23 & & 0 & 0 & 9 & 17 & 31 & 4.39 & 87.7 & Tinggi \\
\hline 24 & & 0 & 1 & 12 & 18 & 28 & 4.25 & 84.9 & Tinggi \\
\hline 25 & & 0 & 0 & 15 & 24 & 18 & 4.05 & 81.1 & Tinggi \\
\hline 26 & & 0 & 0 & 9 & 22 & 28 & 4.30 & 86.0 & Tinggi \\
\hline \multirow[t]{2}{*}{27} & & 0 & 0 & 15 & 20 & 22 & 4.12 & 82.5 & Tinggi \\
\hline & Jumlah & 0 & 2 & 88 & 138 & 173 & 4.20 & 84.1 & Tinggi \\
\hline 28 & \multirow{3}{*}{$\begin{array}{l}\text { Cepat memahami situasi } \\
\text { yang berkembang /mahir } \\
\text { beradaptasi dalam berfikir }\end{array}$} & 0 & 0 & 11 & 14 & 32 & 4.37 & 87.4 & Tinggi \\
\hline 29 & & 0 & 0 & 14 & 17 & 26 & 4.21 & 84.2 & Tinggi \\
\hline \multirow[t]{2}{*}{30} & & 0 & 0 & 9 & 20 & 28 & 4.33 & 86.7 & Tinggi \\
\hline & Jumlah & 0 & 0 & 34 & 51 & 86 & 4.30 & 86.1 & Tinggi \\
\hline 31 & \multirow{5}{*}{$\begin{array}{l}\text { Kuat dalam mensintesis } \\
\text { suatu permasalahan }\end{array}$} & 0 & 1 & 11 & 18 & 27 & 4.25 & 84.9 & Tinggi \\
\hline 32 & & 0 & 3 & 11 & 23 & 20 & 4.05 & 81.1 & Tinggi \\
\hline 33 & & 0 & 1 & 10 & 16 & 20 & 4.32 & 86.3 & Tinggi \\
\hline 34 & & 0 & 1 & 12 & 23 & 21 & 4.12 & 82.5 & Tinggi \\
\hline \multirow[t]{3}{*}{35} & & 0 & 5 & 11 & 18 & 23 & 4.04 & 80.7 & Tinggi \\
\hline & Jumlah & 0 & 11 & 55 & 58 & 121 & 4.15 & 83.1 & Tinggi \\
\hline & \multicolumn{6}{|l|}{ Purata } & 4.22 & 84.49 & Tinggi \\
\hline
\end{tabular}

Tabel 4.8 menunjukkan analisis deskriptif frekuensi data, persentase, min dan total capaian responden (TCR) mengikut sub variabel elemen berfikir orisinil (originality). Nilai sub variabel "mampu melahrikan ide baru yang tidak pernah terfikirkan oleh orang lain" mempunyai nilai min 4.21 dengan TCR adalah $84.1 \%$ yang berada pada tahapan "tinggi". Sementara itu nilai sub variabel "mampu berfikir kritis dalam mencari cara-cara baru untuk menyelesaikan masalah", mempunyai nilai min 4.24 dengan TCR adalah $84.8 \%$ yang juga berada pada tahapan "tinggi". Selanjutnya nilai sub variabel "mampu memikirkan hal-hal yang berbeda (sesuatu yang baru)" mempunyai nilai min 4.22 dengan TCR adalah $84.4 \%$ yang berada pada tahapan "tinggi". Begitu juga dengan nilai sub variabel "kemahiran mencari pendekatan dalam menyelesaikan berbagai model permasalahan" mempunyai nilai min 4.20 dengan TCR adalah $84.1 \%$ yang juga berada pada tahapan "tinggi". Nilai sub variabel "cepat memahami situasi yang berkembang dan mahir beradaptasi dalam membuat gagasan berfikir" didapatakan nilai min 4.30 dengan TCR 86.1 berada pada tahapan tinggi. Terakhir nilai sub variabel "kuat dalam mensintesis suatu permasalahan" diperolehi nilai Min 4.15 dengan TCR 83.1 beradap pada tahapan tinggi. Secara keseluruhan diperoleh purata 
kemampuan guru dalam membangun pembelajaran yang boleh menstimulasi elemen berfikir orisinil adalah 4.22 dengan TCR sebesar $84.49 \%$, berada pada tahapan tinggi.

\section{4) Berfikir Terinci (elaboration) suatu kajian di Sekolah Menengah SMP Negeri akreditasi A Kota Padang}

Penjelasan elemen-elemen kreativiitas dalam pembelajaran PLH di Sekolah Menengah SMP Negeri Akreditasi A di daerah Kota Padang untuk pengukuran elemen berfikir terinci dapat dilihat pada tabel berikut ini:

Tabel 4.9: Tahapan Kreativiitas Variabel Berfikir Terinci di SMP Neger Akreditasi A Kota Padang

\begin{tabular}{|c|c|c|c|c|c|c|c|c|c|}
\hline $\begin{array}{l}\text { No } \\
\text { soa } \\
\text { lan }\end{array}$ & $\begin{array}{c}\text { Sub Variabel } \\
\text { Elemen Berfikir } \\
\text { Terperinci (Elaboration) }\end{array}$ & 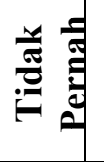 & & 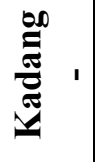 & 䎋 & $\frac{\Xi}{\frac{\Xi}{\pi}}$ & Min & TCR & Kategori \\
\hline 1 & \multirow{4}{*}{$\begin{array}{l}\text { Mahir menjelaskan dan } \\
\text { menyelesaikan } \\
\text { permasalahan secara } \\
\text { terperinci }\end{array}$} & 0 & 2 & 8 & 23 & 24 & 4.21 & 84.2 & Tinggi \\
\hline 2 & & 0 & 1 & 19 & 9 & 28 & 4.12 & 82.5 & Tinggi \\
\hline 3 & & 0 & 2 & 9 & 8 & 38 & 4.44 & 88.8 & Tinggi \\
\hline \multirow[t]{2}{*}{4} & & 0 & 0 & 7 & 8 & 42 & 4.61 & 86.9 & Tinggi \\
\hline & Jumlah & 0 & 5 & 43 & 48 & 132 & 4.35 & 86.9 & Tinggi \\
\hline 5 & \multirow{4}{*}{$\begin{array}{l}\text { Mahir mengembangkan } \\
\text { gagasan oran glain }\end{array}$} & 0 & 3 & 5 & 13 & 36 & 4.44 & 88.8 & Tinggi \\
\hline 6 & & 0 & 0 & 7 & 9 & 41 & 4.60 & 91.9 & Tinggi \\
\hline 7 & & 0 & 2 & 12 & 10 & 33 & 4.30 & 86.0 & Tinggi \\
\hline 8 & & 0 & 2 & 11 & 5 & 39 & 4.42 & 88.4 & Tinggi \\
\hline & Jumlah & 0 & 7 & 35 & 37 & 149 & 4.44 & 88.8 & Tinggi \\
\hline 9 & \multirow{6}{*}{$\begin{array}{l}\text { Mahir menganalisa langkah- } \\
\text { langkah yang tepat dalam } \\
\text { mengambil keptusan untuk } \\
\text { menyelesaikan masalah }\end{array}$} & 0 & 1 & 10 & 6 & 40 & 4.49 & 89.8 & Tinggi \\
\hline 10 & & 0 & 1 & 4 & 9 & 43 & 4.65 & 93.0 & Tinggi \\
\hline 11 & & 0 & 3 & 9 & 9 & 36 & 4.37 & 87.4 & Tinggi \\
\hline 12 & & 0 & 0 & 10 & 14 & 33 & 4.40 & 88.1 & Tinggi \\
\hline 13 & & 0 & 0 & 7 & 18 & 32 & 4.44 & 88.8 & Tinggi \\
\hline \multirow[t]{2}{*}{14} & & 0 & 1 & 10 & 13 & 33 & 4.37 & 87.4 & Tinggi \\
\hline & Jumlah & 0 & 5 & 50 & 69 & 217 & 4.45 & 89.1 & Tinggi \\
\hline 15 & \multirow{6}{*}{$\begin{array}{l}\text { Memiliki rasa keingin } \\
\text { tahuan yang kuat, tidak } \\
\text { mudah puas dengan hasil } \\
\text { yang dicapai }\end{array}$} & 0 & 2 & 9 & 18 & 28 & 4.26 & 85.3 & Tinggi \\
\hline 16 & & 0 & 0 & 17 & 12 & 28 & 4.19 & 83.9 & Tinggi \\
\hline 17 & & 0 & 0 & 22 & 17 & 18 & 3.93 & 78.6 & Sedang \\
\hline 18 & & 0 & 2 & 11 & 11 & 33 & 4.32 & 86.3 & Tinggi \\
\hline 19 & & 0 & 2 & 17 & 24 & 14 & 3.88 & 77.5 & Sedang \\
\hline \multirow[t]{2}{*}{20} & & 0 & 0 & 11 & 15 & 31 & 4.35 & 87.0 & Tinggi \\
\hline & Jumlah & 0 & 6 & 87 & 97 & 152 & 4.15 & 83.1 & Tinggi \\
\hline 21 & \multirow{3}{*}{$\begin{array}{l}\text { Memahami secara detil } \\
\text { dalam mendeskripsikan } \\
\text { sesuatu, gambaran, gagasan } \\
\text { orang lain }\end{array}$} & 0 & 2 & 11 & 19 & 25 & 4.18 & 83.5 & Tinggi \\
\hline 22 & & 0 & 0 & 12 & 17 & 28 & 4.28 & 85.6 & Tinggi \\
\hline \multirow[t]{3}{*}{23} & & 0 & 2 & 9 & 21 & 25 & 4.21 & 84.2 & Tinggi \\
\hline & Jumlah & 0 & 4 & 32 & 57 & 78 & 4.22 & 84.4 & Tinggi \\
\hline & \multicolumn{6}{|l|}{ Purata } & 4.32 & 86.46 & Tinggi \\
\hline
\end{tabular}

Tabel 4.9 menunjukkan analisis deskriptif frekuensi data, persentase, min dan total capaian responden (TCR) mengikut sub variabel elemen berfikir terinci (elaboration). Nilai sub variabel "mahir menjelskan dan menyelesaikan permasalahan secara terperinci" mempunyai nilai min 4.35 dengan TCR adalah $86.9 \%$ yang berada pada tahapan "tinggi". Sementara itu nilai sub variabel "mahir mengembangkan gagasan orang lain" mempunyai nilai min 4.44 dengan TCR adalah $88.8 \%$ yang juga berada pada tahapan "tinggi". Selanjutnya nilai sub variabel "Mahir 
menganalisa langkah-langkah yang tepat dalam mengambil keputusan untuk menyelesaikan soalan" mempunyai nilai min 4.45 dengan TCR adalah $89.1 \%$ yang berada pada tahapan "tinggi". Begitu juga dengan nilai sub variabel "memiliki rasa keingintahuan yang kuat, tidak muadah puas dengan hasil yang dicapai" mempunyai nilai min 4.15 dengan TCR adalah $83.1 \%$ yang juga berada pada tahapan "tinggi". Terakhir nilai sub variabel "memahami secra detil dalam mendeskripsikan sesuatu gambaran, gagasan orang lain" diperolehi nilai Min 4.22 dengan TCR 84.4 beradap pada tahapan tinggi. Secara keseluruhan diperoleh purata kemampuan guru dalam membangun pembelajaran yang boleh menstimulasi elemen berfikir terinci adalah 4.32 dengan TCR sebesar $84.46 \%$, berada pada tahapan tinggi.

\section{b. Analisis Deskriptif Kompetensi Guru Melaksanakan Elemen-Elemen Kreativiitas dalam Pembelajaran Pendidikan Lingkungan Hidup pada SMP Negeri Akreditasi B di Kota Padang}

Penelitian dilaksanakan dengan
menyebarkan angket kepada 57 orang responden guru Pendidilan Lingkungan Hidup (PLH) di SMP Negeri Akreditasi B Kota Padang. Angket menggunakan skala liker yang diberikan dengan alternatif jawaban !) Tidak Pernah, 2) Jarang, 3) Kadang-kdang, 4) Sering dan 5) selalu. Keputusan kompetensi daripada 57 orang guru PLH pada sekolah SMP Negeri Akreditasi B di Kota Padang adalah sebagai berikut:

Gambar 4.1: Elemen Kreativiitas: Satu Kajian Di Sekolah Menengah SMP Negeri Daerah Kota Padang akreditasi B

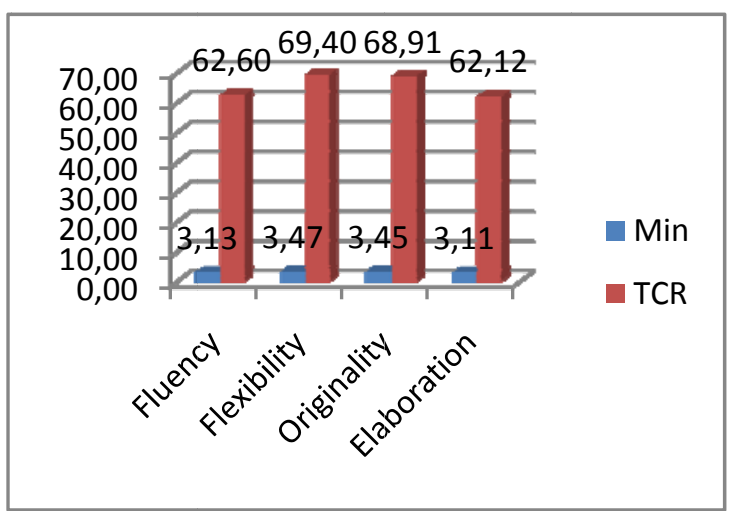

Graf 4.2 menunjukkan tahap kreativiitas satu kajian di Sekolah Menengah SMP Negeri akreditasi B Daerah Kota Padang. Elemen berfikir luwes (flexibility) mempunyai nilai min yang paling tinggi iaitu 3.47 dengan TCR 89.40 , diikuti berfikir origisinil (originality) dengan nilai min 3.45 dan TCR 68.91. kemudian elemen berfikir lancar (fluency) dengan nilai min 3.13 dengan TCR 62.60 dan yang paling rendah adalah berfikir rinci (elaboration) dengan nilai min 3.11 dan TCR 62.12. Ini jelas menunjukkan bahawa elemen berfikir luwes adalah aspek kreativiitas yang paling banyak dimiliki oleh guru-guru yang mengajar pendidikan lingkungan hidup di sekolah SMP Negeri akreditasi B di Kota Padang.

\section{1) Elemen Berfikir Lancar (Fluency) suatu kajian di Sekolah Menengah SMP Negeri Akreditasi B Kota Padang}

Penjelasan elemen-elemen kreativiitas dalam pembelajaran PLH di Sekolah Menengah SMP Negeri Akreditasi B di daerah Kota Padang dapat diuraikan berdasarkan masing-masing elemen-elemen yang diukur yaitu 1) Berfikir Lancar (Fluency), 2) Berfikir Luwes (flexebility), 3) Berfikir orisinil (originality), dan 4) berfikir rinci (elaboration. Untuk lebih jelasnya berikut pengukuran elemen berfikir lancar (fluency)

Tabel 4.11: Tahapan Kreativiitas Variabel Berfikir Lancar di SMP Negeri Akreditasi B Kota Padang

\begin{tabular}{|c|c|c|c|c|c|c|c|c|c|}
\hline $\begin{array}{l}\text { No } \\
\text { soa } \\
\text { Lan }\end{array}$ & $\begin{array}{c}\text { Sub Variabel } \\
\text { Elemen Berfikir Lancar } \\
\text { (Fluency) }\end{array}$ & 兄 霝 & 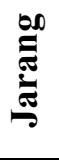 & 唿 & 象 & $\frac{\Xi}{\frac{\Xi}{\pi}}$ & Min & TCR & Kategori \\
\hline 1 & \multirow{4}{*}{$\begin{array}{l}\text { Mengajukan Banyak } \\
\text { Pertanyaan }\end{array}$} & 1 & 3 & 27 & 21 & 5 & 3.44 & 68.8 & Tinggi \\
\hline 2 & & 3 & 1 & 35 & 18 & 2 & 3.18 & 63.5 & Sedang \\
\hline 3 & & 1 & 6 & 33 & 16 & 1 & 3.16 & 63.2 & Sedang \\
\hline 4 & & 2 & 7 & 27 & 18 & 3 & 3.19 & 63.9 & Sedang \\
\hline & Jumlah & 7 & 17 & 122 & 71 & 11 & 3.24 & 64.8 & Sedang \\
\hline 5 & Menjawab Pertanyaan saat & 4 & 1 & 25 & 27 & 0 & 3.25 & 64.9 & Sedang \\
\hline
\end{tabular}




\begin{tabular}{|c|c|c|c|c|c|c|c|c|c|}
\hline 6 & \multirow[t]{3}{*}{ ditanya } & 3 & 4 & 28 & 19 & 3 & 3.21 & 64.2 & Sedang \\
\hline 7 & & 1 & 10 & 27 & 16 & 3 & 3.16 & 63.2 & Sedang \\
\hline \multirow{2}{*}{8} & & 2 & 10 & 30 & 14 & 1 & 3.00 & 60.0 & Rendah \\
\hline & Jumlah & 10 & 25 & 110 & 76 & 7 & 3.15 & 63.1 & Sedang \\
\hline 9 & \multirow[t]{6}{*}{ Mempunyai banyak gagasan } & 1 & 13 & 24 & 15 & 4 & 3.12 & 62.5 & Sedang \\
\hline 10 & & 5 & 17 & 16 & 18 & 1 & 2.79 & 55.8 & Rendah \\
\hline 11 & & 1 & 15 & 21 & 15 & 5 & 3.12 & 62.5 & Sedang \\
\hline 12 & & 1 & 11 & 27 & 17 & 1 & 3.09 & 61.8 & Sedang \\
\hline 13 & & 1 & 18 & 19 & 18 & 1 & 3.00 & 60.0 & Rendah \\
\hline \multirow[t]{2}{*}{14} & & 1 & 4 & 28 & 24 & 0 & 3.30 & 66.0 & Rendah \\
\hline & Jumlah & 10 & 78 & 135 & 107 & 12 & 3.07 & 61.3 & Sedang \\
\hline 15 & \multirow{6}{*}{$\begin{array}{l}\text { Lancar mengungkapkan } \\
\text { gagasan }\end{array}$} & 1 & 7 & 33 & 16 & 0 & 3.11 & 62.1 & Sedang \\
\hline 16 & & 1 & 12 & 35 & 9 & 0 & 2.89 & 57.9 & Rendah \\
\hline 17 & & 1 & 12 & 27 & 11 & 6 & 3.14 & 62.8 & Sedang \\
\hline 18 & & 1 & 21 & 19 & 13 & 3 & 2.91 & 58.2 & Rendah \\
\hline 19 & & 2 & 15 & 30 & 8 & 2 & 2.94 & 58.8 & Rendah \\
\hline \multirow[t]{2}{*}{20} & & 1 & 15 & 23 & 16 & 2 & 3.04 & 60.7 & Sedang \\
\hline & Jumlah & 7 & 82 & 167 & 73 & 13 & 2.99 & 59.8 & Rendah \\
\hline 21 & \multirow{5}{*}{$\begin{array}{l}\text { Berfikir dan bekerja lebih } \\
\text { cepat }\end{array}$} & 1 & 11 & 28 & 12 & 5 & 3.14 & 62.8 & Sedang \\
\hline 22 & & 1 & 3 & 30 & 20 & 3 & 3.35 & 67.0 & Sedang \\
\hline 23 & & 0 & 12 & 22 & 23 & 0 & 3.19 & 63.9 & Sedang \\
\hline 24 & & 2 & 5 & 29 & 17 & 4 & 3.25 & 64.9 & Sedang \\
\hline \multirow[t]{2}{*}{25} & & 1 & 10 & 22 & 24 & 0 & 3.19 & 63.9 & Sedang \\
\hline & Jumlah & 5 & 41 & 131 & 96 & 12 & 3.22 & 64.5 & Sedang \\
\hline 26 & \multirow{5}{*}{$\begin{array}{l}\text { Dapat melakukan koreksi } \\
\text { dengan cepat }\end{array}$} & 1 & 4 & 34 & 16 & 2 & 3.23 & 64.6 & Sedang \\
\hline 27 & & 0 & 4 & 31 & 17 & 5 & 3.40 & 68.1 & Sedang \\
\hline 28 & & 1 & 13 & 33 & 8 & 2 & 2.93 & 58.6 & Rendah \\
\hline 29 & & 1 & 12 & 30 & 14 & 0 & 2.98 & 59.6 & Rendah \\
\hline \multirow[t]{3}{*}{30} & & 2 & 10 & 32 & 10 & 3 & 3.00 & 60.0 & Rendah \\
\hline & Jumlah & 5 & 43 & 160 & 65 & 12 & 3.11 & 62.2 & Sedang \\
\hline & \multicolumn{6}{|l|}{ Purata } & 3.13 & 62.61 & Sedang \\
\hline
\end{tabular}

Tabel 4.11 menunjukkan analisis deskriptif frekuensi data, persentase, min dan total capaian responden (TCR) mengikut sub variabel elemen berfikir lancar (fluency) pada sekolah SMP Negeri akreditasi B Kota Padang. Nilai sub variabel "mengajukan banyak pertanyaan" mempunyai nilai min 3.24 dengan TCR adalah $64.8 \%$ yang berada pada tahapan "sedang". Sementara itu nilai sub variabel "mahir menjawab pertanyaan saat ditanya" mempunyai nilai min 3.15 dengan TCR adalah $63.1 \%$ yang juga berada pada tahapan "sedang". Selanjutnya nilai sub variabel "mempunyai banyak gagasan" mempunyai nilai min 3.07 dengan TCR adalah $61.3 \%$ yang juga berada pada tahapan "sedang". Sebaliknya nilai sub variabel "lancar mengungkapkan gagasan" mempunyai nilai min 2.99 dengan TCR adalah $59.8 \%$ berada pada tahapan "rendah". Nilai tahapan sedang juga didapati pada sub variabel "berfikir dan bekerja lebih cepat dengan nilai min 3.22 dengan TCR 64.5 berada pada tahapan sedang. Terakhir juga diperoleh pada tahapan sedang dengan nilai min nilai Min 3.11 dengan TCR 62.2. Secara keseluruhan diperoleh purata kemampuan guru dalam membangun pembelajaran yang boleh menstimulasi elemen berfikir lancar adalah 3.11 dengan TCR sebesar $62.61 \%$, berada pada tahapan sedang.

\section{Berfikir Luwes (Flexibility) suatu kajian di Sekolah Menengah SMP Negeri akreditasi B Kota Padang}

Penjelasan elemen-elemen kreativiitas dalam pembelajaran PLH di Sekolah Menengah SMP Negeri Akreditasi B di daerah Kota Padang untuk pengukuran elemen berfikir luwes dapat dilihat pada tabel berikut ini: 
Tabel 4.12: Tahapan Kreativiitas Variabel Berfikir Luwes di SMP Negeri Akreditasi B Kota Padang

\begin{tabular}{|c|c|c|c|c|c|c|c|c|c|}
\hline $\begin{array}{l}\text { No } \\
\text { soa } \\
\text { lan }\end{array}$ & $\begin{array}{c}\text { Sub Variabel } \\
\text { Elemen Berfikir Luwes } \\
\text { (Flexibility) }\end{array}$ & 瓷 & 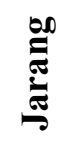 & 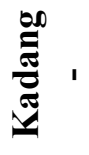 & $\stackrel{00}{:}$ & $\frac{\Xi}{\frac{\pi}{\pi}}$ & Min & TCR & Ket \\
\hline 1 & \multirow{4}{*}{$\begin{array}{l}\text { Kemahiran menggunakan } \\
\text { berbagai objek dalam } \\
\text { pembelajaran }\end{array}$} & 0 & 3 & 22 & 19 & 13 & 3.74 & 74.4 & Sedang \\
\hline 2 & & 0 & 2 & 27 & 19 & 9 & 3.61 & 72.3 & Sedang \\
\hline 3 & & 0 & 3 & 19 & 23 & 12 & 3.77 & 75.4 & Sedang \\
\hline 4 & & 0 & 2 & 24 & 23 & 8 & 3.65 & 73.0 & Sedang \\
\hline & Jumlah & 0 & 10 & 92 & 84 & 42 & 3.69 & 75.9 & Sedang \\
\hline 5 & \multirow{4}{*}{$\begin{array}{l}\text { Kemahiran menafsirkan } \\
\text { berbagai gambar, cerita } \\
\text { dan masalah }\end{array}$} & 0 & 1 & 26 & 21 & 9 & 3.67 & 73.3 & Sedang \\
\hline 6 & & 0 & 3 & 25 & 21 & 8 & 3.60 & 71.9 & Sedang \\
\hline 7 & & 0 & 4 & 20 & 25 & 8 & 3.65 & 73.0 & Sedang \\
\hline \multirow[t]{2}{*}{8} & & 0 & 1 & 30 & 17 & 9 & 3.60 & 71.9 & Sedang \\
\hline & Jumlah & 0 & 9 & 101 & 84 & 34 & 3.63 & 72.5 & Sedang \\
\hline 9 & \multirow{6}{*}{$\begin{array}{l}\text { Kemahrian menerapkan } \\
\text { konsep dengan berbagai } \\
\text { cara }\end{array}$} & 0 & 16 & 17 & 26 & 8 & 3.63 & 72.6 & Sedang \\
\hline 10 & & 0 & 4 & 22 & 23 & 8 & 3.61 & 72.3 & Sedang \\
\hline 11 & & 0 & 14 & 15 & 17 & 11 & 3.44 & 68.8 & Sedang \\
\hline 12 & & 0 & 6 & 30 & 20 & 1 & 3.28 & 65.6 & Sedang \\
\hline 13 & & 0 & 9 & 29 & 13 & 6 & 3.28 & 65.6 & Sedang \\
\hline \multirow[t]{2}{*}{14} & & 0 & 4 & 26 & 24 & 3 & 3.46 & 69.1 & Sedang \\
\hline & Jumlah & 0 & 43 & 139 & 123 & 37 & 3.45 & 69.0 & Sedang \\
\hline 15 & \multirow{6}{*}{$\begin{array}{l}\text { Kemahiran mengatasi } \\
\text { berbagai situasi }\end{array}$} & 0 & 2 & 33 & 17 & 5 & 3.44 & 69.8 & Sedang \\
\hline 16 & & 0 & 9 & 40 & 8 & 0 & 2.98 & 59.6 & Rendah \\
\hline 17 & & 0 & 9 & 36 & 2 & 10 & 3.23 & 64.6 & Sedang \\
\hline 18 & & 0 & 11 & 31 & 6 & 9 & 3.23 & 64.6 & Sedang \\
\hline 19 & & 0 & 9 & 33 & 9 & 6 & 3.21 & 64.2 & Sedang \\
\hline \multirow[t]{2}{*}{20} & & 0 & 7 & 31 & 11 & 8 & 3.35 & 67.0 & Sedang \\
\hline & Jumlah & 0 & 47 & 204 & 50 & 41 & 3.25 & 65.0 & Sedang \\
\hline 21 & \multirow{7}{*}{$\begin{array}{l}\text { Kemahiran melahirkan } \\
\text { ide-ide baru }\end{array}$} & 0 & 2 & 19 & 19 & 17 & 3.89 & 77.9 & Sedang \\
\hline 22 & & 0 & 2 & 22 & 22 & 11 & 3.47 & 74.7 & Sedang \\
\hline 23 & & 0 & 6 & 20 & 18 & 13 & 3.67 & 73.3 & Sedang \\
\hline 24 & & 0 & 6 & 30 & 12 & 9 & 3.42 & 68.4 & Sedang \\
\hline 25 & & 0 & 3 & 32 & 19 & 3 & 3.39 & 67.7 & Sedang \\
\hline 26 & & 0 & 1 & 30 & 18 & 8 & 3.58 & 71.6 & Sedang \\
\hline \multirow[t]{2}{*}{27} & & 0 & 1 & 34 & 12 & 10 & 3.54 & 70.9 & Sedang \\
\hline & \begin{tabular}{|l} 
Jumlah \\
\end{tabular} & 0 & 21 & 187 & 120 & 71 & 3.60 & 72.1 & Sedang \\
\hline 28 & \multirow{5}{*}{$\begin{array}{l}\text { Mampu menyelesaikan } \\
\text { permasalahan dengan cara } \\
\text { yang berbeda }\end{array}$} & 0 & 7 & 35 & 6 & 9 & 3.30 & 66.0 & Sedang \\
\hline 29 & & 0 & 5 & 26 & 20 & 6 & 3.47 & 69.5 & Sedang \\
\hline 30 & & 0 & 6 & 26 & 19 & 6 & 3.44 & 68.8 & Sedang \\
\hline 31 & & 0 & 6 & 27 & 14 & 10 & 3.49 & 69.8 & Sedang \\
\hline \multirow[t]{2}{*}{32} & & 0 & 8 & 24 & 23 & 2 & 3.33 & 66.7 & Sedang \\
\hline & \begin{tabular}{|l|} 
Jumlah \\
\end{tabular} & 0 & 32 & 138 & 82 & 33 & 3.41 & 68.1 & Sedang \\
\hline 33 & \multirow{5}{*}{$\begin{array}{l}\text { Mahir mengklasifikaskan } \\
\text { permasalahan dengan baik }\end{array}$} & 0 & 3 & 29 & 13 & 12 & 3.60 & 71.9 & Sedang \\
\hline 34 & & 0 & 1 & 30 & 16 & 10 & 3.61 & 72.3 & Sedang \\
\hline 35 & & 0 & 7 & 33 & 6 & 11 & 3.37 & 67.4 & Sedang \\
\hline 36 & & 0 & 8 & 30 & 9 & 10 & 3.37 & 67.4 & Sedang \\
\hline \multirow[t]{2}{*}{37} & & 0 & 13 & 35 & 8 & 1 & 2.98 & 58.9 & Rendah \\
\hline & \begin{tabular}{|l|} 
Jumlah \\
\end{tabular} & 0 & 32 & 149 & 52 & 52 & 3.44 & 68.7 & Sedang \\
\hline 38 & \multirow{2}{*}{$\begin{array}{l}\text { Mampu mengubah arah } \\
\text { berfikir secara spontan }\end{array}$} & 0 & 7 & 28 & 15 & 7 & 3.39 & 67.7 & Sedang \\
\hline 39 & & 0 & 5 & 21 & 19 & 12 & 3.67 & 73.3 & Sedang \\
\hline
\end{tabular}




\begin{tabular}{|c|l|c|c|c|c|c|c|c|c|}
\hline 40 & & 2 & 15 & 29 & 9 & 2 & 2.86 & 57.2 & Rendah \\
\cline { 4 - 10 } 41 & & 1 & 9 & 25 & 16 & 6 & 3.38 & 65.6 & Sedang \\
\cline { 3 - 10 } & & 2 & 10 & 24 & 15 & 6 & 3.19 & 63.9 & Sedang \\
\hline 42 & Jumlah & 5 & 45 & 124 & 70 & 40 & $\mathbf{3 . 3 1}$ & $\mathbf{6 6 . 2}$ & Sedang \\
\hline & Purata & \multicolumn{10}{|c|}{} & & $\mathbf{3 . 4 7}$ & $\mathbf{6 9 . 4 4}$ & Sedang \\
\hline
\end{tabular}

Tabel 4.12 menunjukkan analisis deskriptif frekuensi data, persentase, min dan total capaian responden (TCR) mengikut sub variabel elemen berfikir luwes (flexibility). Nilai sub variabel "kemahiran menggunakan berbagai obek dalam pembelajaran" mempunyai nilai min 3.69 dengan TCR adalah $75.9 \%$ yang berada pada tahapan "sedang". Sementara itu nilai sub variabel "kemahiran menafsirkan berbagai gambar, cerita dan masalah" mempunyai nilai min 3.63 dengan TCR adalah $72.5 \%$ yang juga berada pada tahapan "sedang". Selanjutnya nilai sub variabel "kemahiran mengatasi berbagai situasi" mempunyai nilai min 3.25 dengan TCR adalah $65.0 \%$ yang juga berada pada tahapan "sedang". Begitu juga dengan nilai sub variabel "kemahiran melahirkan ide-ide baru" mempunyai nilai min 3.60 dengan TCR adalah $72.1 \%$ yang juga berada pada tahapan "sedang". Nilai sub variabel "mahir menyelesaikan masalah dengan cara yang berbeda" didapatakan nilai min 3.41 dengan TCR 68.1 berada pada tahapan sedang. Untuk sub variabel "mahir mengklasifikasikan permasalahan dengan baik" didapatakan nilai min 3.44 dengan TCR 68.7 berada pada tahapan sedang. Terakhir nilai sub variabel "mampu mengubah arah berfikir secra spontan" diperolehi nilai Min 3.31 dengan TCR 66.2 beradap pada tahapan sedang. Secara keseluruhan diperoleh purata kemampuan guru dalam membangun pembelajaran yang boleh menstimulasi elemen berfikir luwes adalah 3.47 dengan TCR sebesar $69.44 \%$, berada pada tahapan sedang.

\section{Berfikir Orisinil (originality) suatu kajian di Sekolah Menengah SMP Negeri akreditasi B Kota Padang}

Penjelasan elemen-elemen kreativiitas dalam pembelajaran PLH di Sekolah Menengah SMP Negeri Akreditasi B di daerah Kota Padang untuk pengukuran elemen berfikir orisinil dapat dilihat pada tabel berikut ini:

Tabel 4.13: Tahapan Kreativiitas Variabel Berfikir Orisinil di SMP Negeri Akreditasi B Kota Padang

\begin{tabular}{|c|c|c|c|c|c|c|c|c|c|}
\hline $\begin{array}{l}\text { No } \\
\text { soa } \\
\text { lan }\end{array}$ & $\begin{array}{c}\text { Sub Variabel } \\
\text { Elemen Berfikir Orisinil } \\
\text { (Originality) }\end{array}$ & 尖 & & 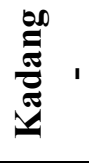 & 㱔 & $\frac{\Xi}{\frac{\pi}{J}}$ & Min & TCR & Kategori \\
\hline 1 & \multirow{4}{*}{$\begin{array}{l}\text { Mampu melahirkan ide baru } \\
\text { yang tidak pernah } \\
\text { terfikirkan orang lain }\end{array}$} & 0 & 3 & 28 & 14 & 12 & 3.61 & 72.3 & sedang \\
\hline 2 & & 0 & 1 & 29 & 18 & 9 & 3.61 & 72.3 & Sedang \\
\hline 3 & & 0 & 7 & 32 & 8 & 10 & 3.37 & 67.4 & Sedang \\
\hline 4 & & 0 & 8 & 32 & 9 & 8 & 3.30 & 66.0 & Sedang \\
\hline & Jumlah & 0 & 19 & 121 & 49 & 39 & 3.47 & 69.5 & Sedang \\
\hline 5 & \multirow{4}{*}{$\begin{array}{l}\text { Mampu berfikir kritis dalam } \\
\text { mencari cara-cara baru } \\
\text { untuk menyelesaikan } \\
\text { masalah }\end{array}$} & 0 & 13 & 27 & 9 & 8 & 3.21 & 64.2 & Sedang \\
\hline 6 & & 0 & 7 & 27 & 16 & 7 & 3.40 & 68.1 & Sedang \\
\hline 7 & & 0 & 5 & 22 & 20 & 10 & 3.61 & 72.3 & Sedang \\
\hline \multirow[t]{2}{*}{8} & & 2 & 14 & 27 & 7 & 7 & 3.02 & 60.4 & Sedang \\
\hline & Jumlah & 2 & 39 & 103 & 52 & 32 & 3.31 & 66.2 & Sedang \\
\hline 9 & \multirow[t]{6}{*}{ Mahir berfikir asimetris } & 0 & 2 & 18 & 20 & 17 & 3.91 & 78.2 & Sedang \\
\hline 10 & & 0 & 2 & 19 & 26 & 10 & 3.77 & 75.4 & Sedang \\
\hline 11 & & 0 & 6 & 19 & 20 & 12 & 3.67 & 73.3 & Sedang \\
\hline 12 & & 0 & 7 & 30 & 13 & 7 & 3.35 & 67.0 & Sedang \\
\hline 13 & & 0 & 4 & 31 & 20 & 2 & 3.35 & 67.0 & Sedang \\
\hline 14 & & 0 & 1 & 30 & 19 & 7 & 3.56 & 71.2 & Sedang \\
\hline & Jumlah & 0 & 22 & 147 & 118 & 55 & 3.60 & 72.0 & Sedang \\
\hline
\end{tabular}




\begin{tabular}{|c|c|c|c|c|c|c|c|c|c|}
\hline 15 & \multirow{6}{*}{$\begin{array}{l}\text { Mampu memikirkan hal-hal } \\
\text { yang berbeda (sesuatu yang } \\
\text { baru) }\end{array}$} & 0 & 2 & 35 & 11 & 9 & 3.47 & 69.5 & Sedang \\
\hline 16 & & 0 & 8 & 36 & 6 & 7 & 3.18 & 63.5 & Sedang \\
\hline 17 & & 0 & 6 & 27 & 18 & 6 & 3.42 & 68.4 & Sedang \\
\hline 18 & & 0 & 8 & 26 & 17 & 6 & 3.37 & 67.4 & Sedang \\
\hline 19 & & 0 & 6 & 25 & 14 & 12 & 3.56 & 71.2 & Sedang \\
\hline 20 & & 0 & 8 & 23 & 23 & 3 & 3.37 & 67.4 & Sedang \\
\hline & Jumlah & 0 & 39 & 172 & 88 & 43 & 3.39 & 67.9 & Sedang \\
\hline 21 & \multirow{7}{*}{$\begin{array}{l}\text { Mahir mencari pendekatan } \\
\text { dalam menyelesaikan } \\
\text { berbagai model } \\
\text { permasalahan }\end{array}$} & 0 & 3 & 28 & 14 & 12 & 3.61 & 72.3 & Sedang \\
\hline 22 & & 0 & 1 & 29 & 18 & 9 & 3.61 & 72.3 & Sedang \\
\hline 23 & & 0 & 7 & 18 & 21 & 11 & 3.63 & 72.6 & Sedang \\
\hline 24 & & 0 & 6 & 32 & 11 & 8 & 3.37 & 67.4 & Sedang \\
\hline 25 & & 1 & 3 & 30 & 21 & 2 & 3.33 & 66.7 & Sedang \\
\hline 26 & & 0 & 2 & 30 & 18 & 7 & 3.53 & 70.5 & Sedang \\
\hline \multirow[t]{2}{*}{27} & & 0 & 1 & 34 & 14 & 8 & 3.51 & 70.2 & Sedang \\
\hline & Jumlah & 1 & 23 & 201 & 117 & 57 & 3.51 & 70.3 & Sedang \\
\hline 28 & \multirow{3}{*}{$\begin{array}{l}\text { Cepat memahami situasi } \\
\text { yang berkembang /mahir } \\
\text { beradaptasi dalam berfikir }\end{array}$} & 0 & 8 & 37 & 5 & 7 & 3.19 & 63.9 & Sedang \\
\hline 29 & & 0 & 5 & 28 & 19 & 5 & 3.42 & 68.4 & Sedang \\
\hline \multirow[t]{2}{*}{30} & & 0 & 6 & 29 & 18 & 4 & 3.35 & 67.0 & Sedang \\
\hline & Jumlah & 0 & 19 & 94 & 42 & 16 & 3.32 & 66.4 & Sedang \\
\hline 31 & \multirow{5}{*}{$\begin{array}{l}\text { Kuat dalam mensintesis } \\
\text { suatu permasalahan }\end{array}$} & 0 & 5 & 25 & 16 & 11 & 3.58 & 71.6 & Sedang \\
\hline 32 & & 0 & 6 & 25 & 23 & 3 & 3.40 & 68.1 & Sedang \\
\hline 33 & & 0 & 4 & 28 & 14 & 11 & 3.56 & 71.2 & Sedang \\
\hline 34 & & 0 & 2 & 27 & 19 & 9 & 3.61 & 72.3 & Sedang \\
\hline \multirow[t]{3}{*}{35} & & 0 & 7 & 32 & 9 & 9 & 3.35 & 67.0 & Sedang \\
\hline & Jumlah & 0 & 24 & 137 & 81 & 43 & 3.50 & 70.0 & Sedang \\
\hline & \multicolumn{6}{|l|}{ Purata } & 3.45 & 68.9 & Sedang \\
\hline
\end{tabular}

Tabel 4.13 menunjukkan analisis deskriptif frekuensi data, persentase, min dan total capaian responden (TCR) mengikut sub variabel elemen berfikir orisinil (originality). Nilai sub variabel "mampu melahrikan ide baru yang tidak pernah terfikirkan oleh orang lain" mempunyai nilai min 3.47 dengan TCR adalah $69.5 \%$ yang berada pada tahapan "sedang". Sementara itu nilai sub variabel "mampu berfikir kritis dalam mencari cara-cara baru untuk menyelesaikan masalah", mempunyai nilai min 3.31 dengan TCR adalah $66.2 \%$ yang juga berada pada tahapan "sedang". Selanjutnya nilai sub variabel "mampu memikirkan hal-hal yang berbeda (sesuatu yang baru)" mempunyai nilai min 3.60 dengan TCR adalah $72.0 \%$ yang berada pada tahapan "sedang". Begitu juga dengan nilai sub variabel "kemahiran mencari pendekatan dalam menyelesaikan berbagai model permasalahan" mempunyai nilai min 3.39 dengan TCR adalah $67.9 \%$ yang juga berada pada tahapan "sedang". Nilai sub variabel "cepat memahami situasi yang berkembang dan mahir beradaptasi dalam membuat gagasan berfikir" didapatakan nilai min 3.32 dengan TCR 66.4 berada pada tahapan sedang. Terakhir nilai sub variabel "kuat dalam mensintesis suatu permasalahan" diperolehi nilai Min 3.50 dengan TCR 70.0 beradap pada tahapan sedang. Secara keseluruhan diperoleh purata kemampuan guru dalam membangun pembelajaran yang boleh menstimulasi elemen berfikir orisinil adalah 3.45 dengan TCR sebesar $68.91 \%$, berada pada tahapan sedang.

\section{4) Berfikir Terinci (elaboration) suatu kajian di Sekolah Menengah SMP Negeri akreditasi B Kota Padang}

Penjelasan elemen-elemen kreativiitas dalam pembelajaran PLH di Sekolah Menengah SMP Negeri Akreditasi B di daerah Kota Padang untuk pengukuran elemen berfikir terinci dapat dilihat pada tabel berikut ini: 
Tabel 4.14: Tahapan Kreativiitas Variabel Berfikir Terinci di SMP Negeri Akreditasi B Kota Padang

\begin{tabular}{|c|c|c|c|c|c|c|c|c|c|}
\hline $\begin{array}{l}\text { No } \\
\text { soa } \\
\text { lan }\end{array}$ & $\begin{array}{c}\text { Sub Variabel } \\
\text { Elemen Berfikir } \\
\text { Terperinci (Elaboration) }\end{array}$ & 卷 & & 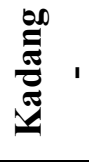 & 㱔 & $\frac{\Xi}{\frac{\Xi}{\pi}}$ & Min & TCR & Kategori \\
\hline 1 & \multirow{4}{*}{$\begin{array}{l}\text { Mahir menjelaskan dan } \\
\text { menyelesaikan } \\
\text { permasalahan secara } \\
\text { terperinci }\end{array}$} & 1 & 4 & 27 & 25 & 0 & 3.32 & 66.3 & Sedang \\
\hline 2 & & 0 & 10 & 39 & 8 & 0 & 2.96 & 59.3 & Rendah \\
\hline 3 & & 0 & 10 & 40 & 7 & 0 & 2.95 & 58.9 & Rendah \\
\hline \multirow[t]{2}{*}{4} & & 0 & 22 & 27 & 7 & 1 & 2.77 & 55.4 & Rendah \\
\hline & Jumlah & 1 & 46 & 133 & 47 & 1 & 3.00 & 60.00 & Rendah \\
\hline 5 & \multirow{4}{*}{$\begin{array}{l}\text { Mahir mengembangkan } \\
\text { gagasan oran glain }\end{array}$} & 0 & 7 & 27 & 23 & 0 & 3.28 & 65.6 & Sedang \\
\hline 6 & & 0 & 9 & 37 & 11 & 0 & 3.04 & 60.7 & Sedang \\
\hline 7 & & 0 & 17 & 33 & 7 & 0 & 2.82 & 56.5 & Rendah \\
\hline \multirow[t]{2}{*}{8} & & 0 & 19 & 32 & 6 & 0 & 2.77 & 55.4 & Rendah \\
\hline & Jumlah & 0 & 52 & 129 & 47 & 0 & 2.98 & 59.6 & Rendah \\
\hline 9 & \multirow{6}{*}{$\begin{array}{l}\text { Mahir menganalisa langkah- } \\
\text { langkah yang tepat dalam } \\
\text { mengambil keptusan untuk } \\
\text { menyelesaikan masalah }\end{array}$} & 0 & 19 & 24 & 14 & 0 & 2.91 & 58.2 & Rendah \\
\hline 10 & & 6 & 24 & 18 & 8 & 1 & 2.44 & 48.8 & Rendah \\
\hline 11 & & 0 & 8 & 32 & 16 & 1 & 3.18 & 63.5 & Sedang \\
\hline 12 & & 0 & 5 & 24 & 26 & 2 & 3.44 & 68.8 & Rendah \\
\hline 13 & & 0 & 10 & 20 & 24 & 3 & 3.35 & 67.0 & Sedang \\
\hline \multirow[t]{2}{*}{14} & & 0 & 6 & 29 & 18 & 4 & 3.35 & 67.0 & Sedang \\
\hline & Jumlah & 6 & 72 & 147 & 106 & 11 & 3.11 & 62.2 & Sedang \\
\hline 15 & \multirow{6}{*}{$\begin{array}{l}\text { Memiliki rasa keingin } \\
\text { tahuan yang kuat, tidak } \\
\text { mudah puas dengan hasil } \\
\text { yang dicapai }\end{array}$} & 0 & 4 & 21 & 28 & 4 & 3.56 & 71.2 & Sedang \\
\hline 16 & & 1 & 9 & 31 & 15 & 1 & 3.09 & $\begin{array}{l}61.8 \\
\end{array}$ & Sedang \\
\hline 17 & & 0 & 5 & 24 & 26 & 2 & 3.44 & 68.8 & Sedang \\
\hline 18 & & 0 & 17 & 21 & 16 & 3 & 3.09 & $\begin{array}{l}61.8 \\
\end{array}$ & Sedang \\
\hline 19 & & 0 & 10 & 21 & 25 & 1 & 3.30 & 66.0 & Sedang \\
\hline \multirow[t]{2}{*}{20} & & 4 & 7 & 20 & 24 & 2 & 3.16 & 63.2 & Sedang \\
\hline & Jumlah & 5 & 52 & 138 & 134 & 13 & 3.27 & 65.4 & Sedang \\
\hline 21 & \multirow{3}{*}{$\begin{array}{l}\text { Memahami secara detil } \\
\text { dalam mendeskripsikan } \\
\text { sesuatu, gambaran, gagasan } \\
\text { orang lain }\end{array}$} & 0 & 14 & 19 & 22 & 2 & 3.21 & 64.2 & Sedang \\
\hline 22 & & 0 & 4 & 33 & 20 & 0 & 3.28 & 65.6 & Sedang \\
\hline \multirow[t]{3}{*}{23} & & 0 & 15 & 26 & 16 & 0 & 3.02 & 60.4 & Sedang \\
\hline & Jumlah & 0 & 33 & 78 & 58 & 2 & 3.17 & $\begin{array}{l}63.4 \\
\end{array}$ & Sedang \\
\hline & \multicolumn{6}{|l|}{ Purata } & 3.11 & 62.12 & Sedang \\
\hline
\end{tabular}

Tabel 4.14 menunjukkan analisis deskriptif frekuensi data, persentase, min dan total capaian responden (TCR) mengikut sub variabel elemen berfikir terinci (elaboration). Nilai sub variabel "mahir menjelskan dan menyelesaikan permasalahan secara terperinci" mempunyai nilai min 3.00 dengan TCR adalah $60.0 \%$ yang berada pada tahapan "rendah". Sementara itu nilai sub variabel "mahir mengembangkan gagasan orang lain" mempunyai nilai min 2.98 dengan TCR adalah $59.6 \%$ yang juga berada pada tahapan "rendah". Selanjutnya nilai sub variabel "Mahir menganalisa langkah-langkah yang tepat dalam mengambil keputusan untuk menyelesaikan soalan" mempunyai nilai min 3.11 dengan TCR adalah 62.2.1 \% yang berada pada tahapan "sedang". Begitu juga dengan nilai sub variabel "memiliki rasa keingintahuan yang kuat, tidak muadah puas dengan hasil yang dicapai" mempunyai nilai min 3.27 dengan TCR adalah $65.4 \%$ yang juga berada pada tahapan "sedang". Terakhir nilai sub variabel "memahami secra detil dalam mendeskripsikan sesuatu gambaran, gagasan orang lain" diperolehi nilai Min 3.17 dengan TCR 63.4 beradap pada tahapan "sedang". Secara keseluruhan diperoleh purata kemampuan guru dalam membangun pembelajaran yang boleh menstimulasi elemen berfikir terinci adalah 3.11 dengan TCR sebesar $62.12 \%$, berada pada tahapan sedang. 
b. Perbandingan Kreativitas Sekolah akreditasi

\section{A dan B}

1) Perbandingan Kreativitias Elemen Berfikir Lancar (Fluency) antara SMP akreditasi A dan B Kota Padang (Hipotesis 1)

Hasil uji statistik parametrik dengan untuk variabel kreativitas elemen berfikir lancar antara SMP akreditasi A dan SMP akreditasi B di Kota Padang dapat dilihat seperti pada tabel 4:15.di bawah

Jadual 4.15 : Perbandingan Kreativitas Elemen Berfikir Lancar antara SMP akreditasi A dan B Kota Padang

\begin{tabular}{|l|c|c|l|l|}
\hline Data & t-hitung & Sig & Df & Tahap \\
\hline Perbandingan & 4.729 & 0.03 & 208 & 0.031 \\
Elemen & & 1 & & $<0,05$ \\
berfikir lancar & & & & Signifi \\
SMP & & & & kan \\
akreditasi A & & & & \\
dan B & & & & \\
\hline
\end{tabular}

Sumber: Hasil pemprosesan data utama, 2015

Hasil output SPSS 17.0 menunjukkan taraf signifikan $0.031<0.05$, yang maksudnya bahawa terdapat perbedaan signifikan kreativitas elemen berfikir lancar antara pelajar yang mengikuti pembelajaran PLH di SMP akreditasi A dan SMP akreditasi B di Kota Padang. Capaian kreativitas elemen berfikir lancar SMP akreditasi A lebih lebih tinggi daripada kelas PLH SMP akreditasi B.

2) Perbandingan Kreativitias Elemen Berfikir Luwes (Flexible) antara SMP akreditasi A dan B Kota Padang (Hipotesis 2)

Hasil uji statistik parametrik dengan untuk variabel kreativitas elemen berfikir luwes antara SMP akreditasi A dan SMP akreditasi B di Kota Padang dapat dilihat seperti pada tabel 4:16.di bawah

Jadual 4.16 : Perbandingan Kreativitas Elemen Berfikir Luwes antara SMP akreditasi A dan B Kota Padang

\begin{tabular}{|l|c|c|c|l|}
\hline Data & t-hitung & Sig & Df & Tahap \\
\hline Perbandinga & 5.867 & 0.01 & 20 & $0.016<$ \\
n Elemen & & 6 & 8 & 0,05 \\
berfikir & & & & $\begin{array}{l}\text { Signifik } \\
\text { luwes SMP }\end{array}$ \\
$\begin{array}{l}\text { akreditasi A } \\
\text { dan B }\end{array}$ & & & & an \\
\hline
\end{tabular}

Sumber: Hasil pemprosesan data utama, 2015
Hasil output SPSS 17.0 menunjukkan taraf signifikan $0.016<0.05$, yang maksudnya bahawa terdapat perbedaan signifikan kreativitas elemen berfikir luwes antara pelajar yang mengikuti pembelajaran PLH di SMP akreditasi A dan SMP akreditasi B di Kota Padang. Capaian kreativitas elemen berfikir luwes SMP akreditasi A lebih lebih tinggi daripada kelas PLH SMP akreditasi B.

\section{3) Perbandingan Kreativitias Elemen Berfikir Orisinil (original) antara SMP akreditasi A dan B Kota Padang (Hipotesis 3)}

Hasil uji statistik parametrik dengan untuk variabel kreativitas elemen berfikir orisinil antara SMP akreditasi A dan SMP akreditasi B di Kota Padang dapat dilihat seperti pada tabel 4:17.di bawah

Jadual 4.17 : Perbandingan Kreativitas Elemen Berfikir Orisinil antara SMP akreditasi A dan B Kota Padang

\begin{tabular}{|l|c|c|c|l|}
\hline Data & t-hitung & Sig & Df & Tahap \\
\hline Perbandinga & 7.334 & 0.04 & 2 & $0.043<$ \\
n Elemen & & 3 & 0 & 0,05 \\
berfikir & & & 8 & Signifik \\
$\begin{array}{l}\text { orisinil SMP } \\
\text { akreditasi A } \\
\text { dan B }\end{array}$ & & & & an \\
\hline
\end{tabular}

Sumber: Hasil pemprosesan data utama, 2015

Hasil output SPSS 17.0 menunjukkan taraf signifikan $0.043<0.05$, yang maksudnya bahawa terdapat perbedaan signifikan kreativitas elemen berfikir orisinil antara pelajar yang mengikuti pembelajaran PLH di SMP akreditasi A dan SMP akreditasi B di Kota Padang. Capaian kreativitas elemen berfikir orisinil SMP akreditasi A lebih lebih tinggi daripada kelas PLH SMP akreditasi B.

4) Perbandingan Kreativitias Elemen Berfikir terinci (elaboration) antara SMP akreditasi A dan B Kota Padang (Hipotesis 3)

Hasil uji statistik parametrik dengan untuk variabel kreativitas elemen berfikir terinci antara SMP akreditasi A dan SMP akreditasi B di Kota Padang dapat dilihat seperti pada tabel 4:18.di bawah

Jadual 4.18 : Perbandingan Kreativitas Elemen Berfikir Orisinil antara SMP akreditasi A dan B Kota Padang 


\begin{tabular}{|l|c|c|c|l|}
\hline Data & t-hitung & Sig & Df & Tahap \\
\hline Perbandingan & 14.72 & 0.00 & 20 & $0.004<$ \\
$\begin{array}{l}\text { Elemen berfikir } \\
\text { terinci SMP }\end{array}$ & & 4 & 8 & 0,05 \\
$\begin{array}{l}\text { akreditasi A } \\
\text { dan B }\end{array}$ & & & & $\begin{array}{l}\text { Signifik } \\
\text { an }\end{array}$ \\
\hline
\end{tabular}

Sumber: Hasil pemprosesan data utama, 2015

Hasil output SPSS 17.0 menunjukkan taraf signifikan $0.004<0.05$, yang maksudnya bahawa terdapat perbedaan signifikan kreativitas elemen berfikir terinci antara pelajar yang mengikuti pembelajaran PLH di SMP akreditasi A dan SMP akreditasi B di Kota Padang. Capaian kreativitas elemen berfikir terinci SMP akreditasi A lebih lebih tinggi daripada kelas PLH SMP akreditasi B.

\section{SIMPULAN DAN SARAN}

Perbandingan kompetensi profesional guru dalam membangun pembelajaran kreatif pada muatan lokal pendidikan lingkungan hidup menunjukkan adanya perbedaan kreatvitas yang signifikan antara guru-guru yang mengajarkan materi PLH di SMP Negeri akreditasi A dengan SMP Negeri akreditasi B di Kota Padang. Dari 4 variabel kreativitas yang diteliti yaitu 1) berfikir lancar (fluency), berfikir luwes (flexible), berfikir orisinil (original) dan berfikir terinci (elaboration) di dapatkan hasil bahwa guru-guru di SMP Negeri akreditasi A jauh lebih baik membangun model pembelajaran kreatif di bandingkan SMP Negeri akreditasi B di kota Padang. Hal ini disebabkan krena sebagian besar guru-guru PLH di SMP Negeri akreditasi A sudah banyak mengikuti pelatihan bimtek di sekolah dibandingkan guruguru PLH di SMP Negeri akreditasi B, dimana jumlah pelatihan yang diikuti jauh lebih banyak pada guru-guru PLH di SMP Negeri akreditasi A.

Selain itu baiknya dan berhasilkan guruguru PLH di SMP Negeri akreditasi A membangun model pembelajaran kreatif di banding SMP Negeri akreditasi B adalah dari segi fasilitas, sarana dan prasana pembelajaran, dimana SMP Negeri akreditasi A memiliki sarana dan fasilitas pembelaaran yang jauh lebih lengkap dari SMP Negeri akreditasi B. Begitu juga dengan Input kualitas siswa antar kedua sekolah ini juga berbeda dari proses penyeleksian pelajarnya saat penerimaan siswa baru, dimana SMP Negeri akreditasi A merekrut pelajar yang memang sudah memiliki prestasi akademik lebih tinggi dibanding SMP Negeri akreditasi B. Sehingga dapat disimpulan adanya perbedaan signifikan capaian model pembelajaran kreatif pada materi PLH oleh guru-guru PLH di SMP Negeri akreditasi A dan B lebh umum disebabkan oleh perbedaan jam terbang mengajar, perbedaan mengikuti pelatihan, perbedaan fasilitas dan sarana prasarana pembelaajran dan terakhir perbedaan input siswa dari segi IQ saat penerimaan siswa baru berdasarkan prestasi akademik juga berbeda dimana SMP Negeri akreditasi A merekrut pelajar $\mathrm{y}$ ang memiliki reputasi dan prestasi akademik lebih tinggi dari SMP Negeri akreditasi B .

\section{DAFTAR PUSTAKA}

Creswell, John. W. 2007. Educational Research Planning, Conducting and Evaluating, Quantitative and Qualitatitive Research. Pearson Prentice Hall.

Joyce, B. dan Weil, M. (2000). Models of Teaching. (Fourth Edition). Needham Heights Massachusetts: Allyn \& Bacon.

Joyce, B. dan Weil, M. (2000). Models of Teaching. Boston: A Pearson education Company.

Munandar, S.C.U. (2005). Kreativiti dan

Keberbakatan: Strategi Mewujudkan

Potensi Kreatif dan Bakat. Jakarta: PT. Gramedia Pustaka.

Munandar, S.C.U. (2002). Mengembangkan Bakat dan Kreativiti Anak Sekolah: Petunjuk bagi Guru dan Orang Tua. Jakarta: Grasindo.

Plom et all (1999) Creative Behavior Guidebook. New York: Charles Scribners's.

Sternberg, 2003. Perspectives in Creativity. Chicago: Aldine Pub. Co.

Supriadi, 2004. Strategi Pembelajaran Berorientasi Standar Proses Pendidikan. Jakarta: Prenada Media Group.

Treffinger, D. J. (1980). Encouraging Creative Learning for Gifted and Talented. Ventura, Ca.: Ventura County Superintendent of Schools Office. 